\title{
PEGXIT PRESSURE: \\ EVIDENCE FROM THE CLASSICAL GOLD STANDARD
}

\author{
Kris James Mitchener \\ Gonçalo Pina \\ Working Paper 22844 \\ http://www.nber.org/papers/w22844 \\ NATIONAL BUREAU OF ECONOMIC RESEARCH \\ 1050 Massachusetts Avenue \\ Cambridge, MA 02138 \\ November 2016
}

We thank Sanjiv Das, Andrew Rose, Jaume Ventura, Robert Zymek, as well as seminar participants at Santa Clara University and University of California Santa Cruz, and conference participants at the Fourth CEPR Economic History Symposium and the 5th West Coast Workshop in International Finance for helpful comments and suggestions. We also thank Michael Hultquist, Roya Seyedein and Xindi Sun for excellent research assistance. The views expressed herein are those of the authors and do not necessarily reflect the views of the National Bureau of Economic Research.

NBER working papers are circulated for discussion and comment purposes. They have not been peer-reviewed or been subject to the review by the NBER Board of Directors that accompanies official NBER publications.

(C) 2016 by Kris James Mitchener and Gonçalo Pina. All rights reserved. Short sections of text, not to exceed two paragraphs, may be quoted without explicit permission provided that full credit, including $\odot$ notice, is given to the source. 
Pegxit Pressure: Evidence from the Classical Gold Standard

Kris James Mitchener and Gonçalo Pina

NBER Working Paper No. 22844

November 2016

JEL No. F31,F33,F36,N10,N20

\section{ABSTRACT}

We develop a simple model that highlights the costs and benefits of fixed exchange rates as they relate to trade, and show that negative export-price shocks reduce fiscal revenue and increase the likelihood of an expected currency devaluation. Using a new high-frequency data set on commodity-price movements from the classical gold standard era, we then show that the model's main prediction holds even for the canonical example of hard pegs. We identify a negative causal relationship between export-price shocks and currency-risk premia in emerging market economies, indicating that negative export-price shocks increased the probability that countries abandoned their pegs.

Kris James Mitchener

Department of Economics

Leavey School of Business

Santa Clara University

Santa Clara, CA 95053

and NBER

kmitchener@scu.edu

Gonçalo Pina

Santa Clara University

gpina@scu.edu 


\section{Introduction}

A recurrent feature of the international monetary system over the past 150 years has been the use of fixed exchange rates to anchor currency values and prices. Fixed exchange rates have some macroeconomic benefits (Edwards et al. 2003; López-Córdova and Meissner 2003; Husain et al. 2005), but abandoning a fixed-exchange rate regime is one of the most frequently observed policy decisions in open-economy macroeconomics (Obstfeld and Rogoff 1995; Reinhart and Rogoff 2009). This decision is frequently followed by a currency devaluation, which can result in significant reductions in employment and output (Kaminsky and Reinhart 1999; Gupta et al. 2007). Given the fragility of fixed exchange rates, countries often turn to hard pegs and currency unions. But as shown by Schmukler and Servén (2002) and Mitchener and Weidenmier (2015), even hard pegs have rarely been viewed as credible arrangements by financial markets.

In this paper, we illustrate one reason why countries abandon pegs and devalue their currencies: shocks to the value of their output. We take the perspective that fixed exchange rates are often adopted to facilitate external trade, and explore how exogenous fluctuations in export prices affect the probability of expected currency devaluation. To do so, we first solve a long-run model with flexible prices where a government chooses an optimal policy by weighing the costs and benefits of abandoning a fixed exchange rate. The cost of floating is that trade is lower outside of a fixed exchange-rate regime, reducing government tax revenues and increasing fiscal pressure. ${ }^{1}$ The benefit of floating is that, in real terms, the government faces

\footnotetext{
${ }^{1}$ There are a variety of reasons why trade may be larger under a peg, including lower exchange rate volatility and transaction costs. The empirical literature on the classical gold standard suggests that trade was larger under pegs due to transactions costs (López-Córdova and Meissner, $2003)$.
} 
lower domestic-currency debt payments following devaluation, reducing the real debt burden and easing fiscal pressure. Optimal policy balances these two effects for a fixed level of debt and a fixed devaluation.

The main contribution of the model is to highlight how permanent shocks to the international price of exports affect the probability of leaving a currency peg. When export prices are sufficiently low, the costs of a reduction in trade after leaving the peg are small and offset by the fixed benefit from lower real-debt payments following devaluation. If export-price shocks are permanent, a negative price shock will increase the probability that export prices are sufficiently low in the future to induce a peg exit, and therefore cause an immediate increase in currency risk. We solve this structural model of abandoning a peg in closed form to show how negative (positive) shocks to the price of a country's exports increase (decrease) the probability of leaving a peg and devaluing its currency.

We then show empirically, using both structural and reduced-form models, that this mechanism is relevant for "pegxit pressure" using currency risk, a closely followed indicator of expected currency devaluation by economic agents, policy makers, and market participants. We employ novel high-frequency panel data that includes monthly measures of commodity and manufactured goods world prices, countries' principal exports, and currency risk, measured from market expectations, for more than 40 years and 21 countries to test whether export-price shocks influence currency risk.

Our sample period, 1870-1913, is a particularly well-suited laboratory for understanding why countries abandon hard pegs for several reasons. First, many 
countries pegged to gold to facilitate trade. ${ }^{2}$ Second, both capital and goods markets were unfettered and integrated (Eichengreen, 1998). Finally, many countries, particularly those in the periphery, had relatively unspecialized production structures, exposing them to external trade shocks that were plausibly exogenous (Williamson, 2013). Trade in this early era of globalization is well described by the Heckscher-Ohlin model of comparative advantage in factor endowments. ${ }^{3}$ Since many countries specialized in exports of raw materials and minerals, we are able to exploit the so-called "commodity lottery" in our identification strategy. That is, commodity prices determined in world markets provide a reasonably exogenous source of variation for measuring the benefits of fixed exchange rates since countries specialized in exporting products based on their pre-determined factor endowments. We focus on the prices of the principal export, instead of export prices or terms-of-trade, as a way to isolate exogenous monthly variation and identify the causal impact of the principal-export price on currency risk under fixed exchange rates. ${ }^{4}$

Our empirical analysis shows a negative and statistically significant causal relationship between the price of principal exports and currency risk, a result that is robust to alternative specifications, including those with country and year fixed effects that account for omitted covariates. Furthermore, we show that the ef-

\footnotetext{
${ }^{2}$ See, for example, Eichengreen (1998), López-Córdova and Meissner (2003), Mitchener and Weidenmier (2008), Mitchener et al. (2010), Mitchener and Voth (2011).

${ }^{3}$ See Blattman et al. (2007), Findlay and O'Rourke (2003), Mitchener and Yan (2014) and O'Rourke and Williamson (1994).

${ }^{4}$ An alternative empirical strategy would be to predict departures from the gold standard using principal-export prices. However, as we later show in Table 11 shows, there were only a few "pegxits" before this international monetary system was abandoned in 1914. Instead, we focus on currency risk spreads since they measure expected currency devaluation, which for pegs, includes the probability of abandoning gold as well as changes in the value of currency following exit.
} 
fects are driven by countries in the periphery rather than the core countries of the gold standard. In particular, for a periphery country that is formally on gold, we find that a one-standard-deviation decrease in the annual growth rate of principalexport prices increases the currency risk spread by 8 basis points. ${ }^{5}$

The main contribution of our paper is to identify a novel mechanism, both theoretically and empirically, that explains the dynamics of currency risk. This research contributes to the large literature on how unsustainable pegs collapse, where it is often difficult to perform causal inference. First-generation models of currency crises highlight a fiscal mechanism where government expenditures need to be financed with inflation-related revenues (for example, seigniorage), but inflation is incompatible with fixed exchange rates under capital mobility (Krugman 1979; Flood and Garber 1984; Calvo 1987; Broner 2008). ${ }^{6}$ However, government expenditure shocks are frequently endogenous or coincide with other shocks such as wars, natural disasters and policy shifts, making it challenging to identify, empirically, how important this fiscal mechanism is in driving currency risk. ${ }^{7}$ To address this identification issue, we focus on a model and an estimation strategy that turns to fiscal shocks emanating from the revenue side of the ledger. Doing so allows us to identify a plausibly exogenous source of variation in revenues,

\footnotetext{
${ }^{5}$ From a trader's perspective, small differences in spreads can lead to large profits. Our objective is not to explain the cross-section of currency risk spreads, which is much larger in magnitude. Rather, we aim to uncover the causal effect of realized price fluctuations on currency risk spreads, on top of other factors that are already priced in.

${ }^{6}$ Another class of models, known as second-generation models, shows that crises can be unpredictable and caused by self-fulfilling expectations, often independently of fundamentals (Obstfeld 1986; Angeletos et al. 2007). So-called third-generation models explore how the financial sector interacts with currency crises and how these crises propagate into the real economy. Examples include Corsetti et al. (1999), Krugman (1999) and Aghion et al. (2004).

${ }^{7}$ In related theoretical contributions, Rebelo and Végh (2008) study optimal policy when there are output costs from abandoning a peg, while Aizenman and Glick (2008) show that a fixed exchange rate can lead to a costly exit following a large enough adverse real shock.
} 
global commodity-price shocks, which can be causally tested to see whether they influence the decision to abandon a peg. ${ }^{8}$

We also contribute to the literature on the the optimality of exchange-rate regimes in response to real and nominal shocks (Kollmann 2002; Gali and Monacelli 2005; Schmitt-Grohé and Uribe 2016). We identify the response of currency risk to an exogenous real shock during the classical gold standard (Chernyshoff et al., 2009), which suggests that price fluctuations in a country's principal export(s) impose limits on using fixed exchange rates as a commitment device (Bordo and Rockoff 1996; Obstfeld and Taylor 2003). Our study shows that debt and real shocks put a strain on existing institutions. Flandreau et al. (1998) document that fluctuations in the cost of servicing debt affected the stability of the European countries during the gold standard. We study a similar mechanism, but focus on country-specific export-price shocks. In that sense, our results are also related to the literature on the trilemma (Obstfeld et al., 2005). In an environment of perfect capital mobility, we document that country-specific external shocks that change the relative value of monetary autonomy affect the probability of exchange-rate instability.

Finally, our study contributes to the understanding of the operation and performance of the classical gold standard in the periphery. Economic historians have noted how the gold standard influenced trade flows and how terms-of-trade shocks influenced the pace and pattern of economic development; however, to our knowledge, this paper is the first to analyze and account for how trade shocks affected the

\footnotetext{
${ }^{8}$ See Kaminsky et al. (1998) for a survey of empirical work on predictors of currency crises for the late $20^{\text {th }}$ century. Tables A1 and A4 in Kaminsky et al. (1998) report that only one study considers export prices (Kamin, 1988). No studies cited in this survey consider the price of the principal exogenous export.
} 
durability of the gold standard on the periphery. ${ }^{9}$ That said, our focus on shocks to a country's principal-export price is related to earlier work including Blattman et al. (2007), Williamson (2008) and Reinhart et al. (2016), and our contribution is to relate the effects of principal-export price shocks to currency risk. Further, the role of debt is related to the work of Bordo and Meissner (2006), which documents that an important share of public debt was denominated in domestic currency. The mechanism through which export prices affect currency risk in our model works through the reduction of real payments of debt denominated in domestic currency but, more generally, it applies also to other sources of inflation-related revenues, including seigniorage and the reduction of real payments on nominal government contracts and wages.

\section{Model}

This section derives a simple, long-run model of endogenous currency risk with flexible prices. Capital markets are assumed to be frictionless. All agents have perfect information and are risk neutral. All variables are measured in terms of the numeraire, and to relate it later to the empirical setting, we assume that issued currency is backed by gold in order to fix exchange rates.

\subsection{Production and prices}

Consider a small, open economy, producing an amount, $y$, of a tradable good with a price, $P_{t}$, that is exogenous to the economy and determined in international

\footnotetext{
${ }^{9}$ See López-Córdova and Meissner (2003), Estevadeordal et al. (2003), Flandreau and Maurel (2005), Mitchener and Weidenmier (2008) and Mitchener et al. (2010).
} 
markets. For simplicity, we abstract from output growth and focus on the production of a single tradable good. ${ }^{10}$ We further assume that PPP holds. The price of the tradable good fluctuates according to the following process:

$$
d P_{t}=\mu P_{t} d t+\sigma P_{t} d Z_{t}, P_{0}>0
$$

where $\mu$ and $\sigma$ represent constant mean and volatility of the commodity price growth rate, and $Z_{t}$ is a wiener process. In other words, $P_{t}$ follows a geometric Brownian motion with percentage drift $\mu$ and volatility $\sigma$.

\subsection{Government}

The government appropriates a constant fraction $\tau$ of tradable output as tax revenues and has a subjective discount factor given by $\rho$, which is also the risk-free rate. The expected discounted value of fiscal revenue from potential output at $t=0$ is given by $\frac{\tau P_{0} y}{\rho-\mu}$. We consider a government that issues debt at $t=0$ to finance a public investment that generates a return of $r_{g}$ per unit of time. The expected discounted benefit of issuing debt equals:

$$
E\left[\int_{0}^{\infty} r_{g} e^{-\rho t} d t\right]=\frac{r_{g}}{\rho} .
$$

We assume that the government issues long-term debt in the form of a perpetuity of amount D with debt service C, both denominated in local currency. This debt is not subject to default, but it is denominated in domestic currency and thus

\footnotetext{
${ }^{10}$ More generally, we could have included non-tradable goods and other tradable goods at the expense of notational simplicity. In the model presentation, we will refer to output and exports interchangeably, but the crucial assumption for our results is that the price of output, $P_{t}$, is exogenously determined in world markets, independently of whether it is ultimately traded.
} 
subject to currency risk. ${ }^{11}$

At $t=0$, the government sets a rule whereby the amount of currency issued is directly tied to the numeraire good, gold. That is, the government promises to keep the price level equal to the international price level of 1 . However, the government can not commit to this policy. In fact, there exists a threshold level of export prices, $P^{F}$, at which it is optimal for the government to float the currency, which happens at time $T^{F}=\inf \left\{t \geq 0 \mid P_{t} \leq P^{F}\right\}$, when the international price first falls to $P^{F}$. This policy is determined endogenously based on the trade-off between costs and benefits derived from leaving hard peg. We assume that once the government leaves the hard peg it does not return. ${ }^{12}$ If the country floats, the real value of the debt service goes down to $\frac{C}{S_{t}}$, where $S_{t}=S$ and $S>1$ is the price level after the government floats. ${ }^{13}$ This reduction in debt payments gives the government the incentive to float. However, by increasing exchange-rate volatility and transaction costs (Rose, 2011), it also negatively affects international trade,

\footnotetext{
${ }^{11}$ We focus our analysis on currency risk rather than country or political risk. In the empirical section of the paper, we argue that our measure of risk premia does not include sovereign risk. Although there is a large empirical literature indicating the existence of original sin (i.e., inability to issue foreign debt denominated in home currency), most economies in the late $19^{\text {th }}$ century, including those on the periphery, funded part of their public debt by issuing long-term bonds in domestic currency in the home market, if not in London. See Accominotti et al. (2011) for data on the the share of public debt issued in home currency.

${ }^{12}$ The assumption of lack of commitment follows Bordo and Kydland (1995). We abstract from escape clauses as our export price shocks are arguably not indicative of the emergencies discussed in Bordo and Kydland (1995), e.g., wars. Instead, we focus on the strategic, and irreversible, decision of the government to abandon the peg. Together with the assumptions of flexible export prices and purchasing power parity, this means that our mechanism is driven by long-run considerations related to trade, and not short-term considerations associated with competitive devaluations or currency wars.

${ }^{13}$ The assumption that the currency devalues after leaving gold is motivated by the positive and persistent currency risk premia found for this period by Mitchener and Weidenmier (2015).
} 
which reduces taxable output by a fraction $\lambda \in[0,1]$. This is the cost of floating. ${ }^{14}$

For simplicity, we assume the government has a balanced budget. In particular, we assume that the government can raise lump-sum taxes or give back subsidies $(\Psi)$ such that it does not accumulate assets or issue new debt over time: ${ }^{15}$

$$
\begin{array}{r}
\dot{a}_{t}=\rho a_{t}+\tau P_{t} y_{t}+\Psi_{t}-C=0, \text { fixed } ; \\
\dot{a}_{t}=\rho a_{t}+\tau P_{t} y_{t}(1-\lambda)+\Psi_{t}-\frac{C}{S}=0 \text {, floating } .
\end{array}
$$

Before providing the mathematical details to solve the model, we develop the intuition for our main result - that an exogenous decline in the price of exports increases the probability of leaving the peg and devaluing currency, while an increase in the price of exports leads to a decline in the probability of leaving the peg and devaluation. In other words, we show how exogenous fiscal-revenue shocks affect currency risk. The benefit of devaluation is that the government faces lower real domestic-currency debt payments. The cost is that abandoning a fixed exchange rate negatively lowers external trade. Optimal policy balances these two effects for a pre-determined amount of debt service, $C$, and a fixed devaluation following the abandonment of the peg. Debt payments under fixed devaluations play an important role in our model. Together, they imply that the benefit of abandoning a currency peg is independent from current export prices. This contrasts with the

\footnotetext{
${ }^{14}$ One common government tax during the gold standard was import tariffs. In the model tax revenues fluctuate with export prices, not imports. Under the assumption of balanced trade, imports are equal to exports. More generally, our assumptions capture that the government obtains tax revenues from economic activity that depends on whether the country fixes its exchange rate.

${ }^{15}$ Any payments in gold-denominated debt are included in $\Psi_{t}$. We focus on domestic currency public debt since the government can not affect the real payments on gold-denominated debt through devaluation. The assumption that the government has access to lump-sum taxes and is running a balanced budget is done for simplicity and would not change the results in this paper.
} 
costs of leaving a peg which fluctuate with the international price of exports. As a consequence, if the government leaves the peg when the price of exports is high, it loses significant tax revenues. These costs do not compensate the fixed benefit of abandoning the peg. On the other hand, when the price of exports declines substantially, the cost of leaving the peg is small and is more than compensated by the fixed benefit in the reduction of real-debt payments. Finally, if export prices are subject to permanent shocks, then negative shocks to prices increase the probability of reaching the lower bound on prices such that the government abandons the peg. Therefore, negative shocks to export prices increase the probability that a country leaves the peg and devalues, while the symmetric holds for positive shocks.

\subsection{Pricing sovereign debt and currency risk premia}

In this section we solve for the economy's currency risk premia. Using Ito's lemma, the value of public debt $D$ satisfies:

$$
\rho D=C+\mu P D_{P}+\frac{1}{2} \sigma^{2} P^{2} D_{P P}
$$

which in turn can be written as:

$$
D(P)=A_{0}+A_{1} P+A_{2} P^{X},
$$

where $X$ is the negative root to the equation $\frac{\sigma^{2}}{2} X(X-1)+\mu X-\rho=0$ given by $X=\frac{1}{2}-\frac{\mu}{\sigma^{2}}-\sqrt{\left(\frac{1}{2}-\frac{\mu}{\sigma^{2}}\right)^{2}+\frac{2 \rho}{\sigma^{2}}}<0 .{ }^{16}$

To determine the constants $A_{0}, A_{1}$ and $A_{2}$ we make use of boundary conditions.

\footnotetext{
${ }^{16}$ See Leland (1994) or Shreve (2004).
} 
To obtain $A_{0}$ and $A_{1}$, note that when $\mathrm{P}$ goes to infinity, the country does not leave the peg and its domestic price level is fixed at 1. Therefore, the currency-risk premium is zero and the value of debt is just the discounted value of present value of real payments $\mathrm{C}$ :

$$
\lim D(P)_{P \rightarrow \infty}=\frac{C}{\rho}
$$

From this boundary condition we can see that $A_{0}=\frac{C}{\rho}$ and $A_{1}=0$. When the country abandons the peg, we assumed that the domestic price level jumps to $S>1$, and that the country does not return to the peg. Then, the debt payments following a peg are permanently reduced in real terms to $\frac{C}{S}$, which implies that:

$$
\lim D(P)_{P \rightarrow P^{F}}=\frac{C}{\rho S}
$$

From these two boundary conditions we obtain that $A_{2}=\frac{C}{\rho} \frac{1-S}{S}\left(P^{F}\right)^{-X}$. Using these results we can rewrite the value of the debt as:

$$
\begin{aligned}
D_{t}(P) & =E\left[\int_{t}^{T^{F}} C e^{-\rho(u-t)} d u\right]+E\left[\int_{T^{F}}^{\infty} \frac{C}{S} e^{-\rho(u-t)} d u\right] \\
& =\frac{C}{\rho}\left[1-\frac{S-1}{S}\left(\frac{P_{t}}{P^{F}}\right)^{X}\right]
\end{aligned}
$$

where $E_{t}\left[e^{-\rho\left(T^{F}-t\right)}\right]=\left(\frac{P_{t}}{P^{F}}\right)^{X}$. The term $\frac{S-1}{S}\left(\frac{P_{t}}{P^{F}}\right)^{X}$ corresponds to the currency risk premium. The market value of debt denominated in domestic currency is then equal to a riskless perpetual bond, minus the currency risk premium associated with devaluation. Note that $P^{F}$ is constant and does not depend on current 
macroeconomic conditions.

For a given $\mathrm{C}$, the currency-risk spread is given by $C R S_{t}(P)=\frac{C}{D_{t}(P)}-\rho$ :

$$
C R S_{t}\left(P_{t}\right)=\rho\left[\frac{1}{1-\frac{S-1}{S}\left(\frac{P_{t}}{P^{F}}\right)}-1\right],
$$

where $\frac{\partial C R S}{\partial P_{t}}<0$. In words, lower international prices are associated with higher risk of a country leaving the currency peg and devaluing the currency, which is reflected in risk-neutral risk premia. ${ }^{17}$

\subsection{Decision to float}

In the previous section, we have priced domestically-denominated debt under the assumption that the country floats its currency if export prices are too low. We now solve for the optimal decision when to float and, in particular, for the threshold level of international prices that induces a "pegxit". First, note that the sovereign government's wealth can be written as:

$$
\begin{aligned}
W_{t}(P) & =E\left[\int_{t}^{\infty} \tau P_{t} y e^{-\rho(u-t)} d u\right]-D_{t}(P)+ \\
& E\left[\int_{t}^{\infty} r_{g} D_{t}\left(P_{t}\right) e^{-\rho(u-t)} d u\right]-E\left[\int_{T^{F}}^{\infty} \lambda \tau y P_{t} e^{-\rho(u-t)} d u\right] \\
& =\tau \frac{P_{t} y}{\rho-\mu}-\frac{\tau \lambda y P^{F}}{\rho-\mu}\left(\frac{P_{t}}{P^{F}}\right)^{X}+\frac{C}{\rho}\left(\frac{r_{g}}{\rho}-1\right)\left[1-\frac{S-1}{S}\left(\frac{P_{t}}{P^{F}}\right)^{X}\right],
\end{aligned}
$$

where $E_{t}\left[\int_{T^{F}}^{\infty} P_{t} e^{-\rho(u-t)} d u\right]=E_{t}\left[P^{F} e^{-\rho\left(T^{F}-t\right)}\right]=P^{F}\left(\frac{P_{t}}{P^{F}}\right)^{X}$

\footnotetext{
${ }^{17}$ Given that $X=\frac{1}{2}-\frac{\mu}{\sigma^{2}}-\sqrt{\left(\frac{1}{2}-\frac{\mu}{\sigma^{2}}\right)^{2}+\frac{2 \rho}{\sigma^{2}}}<0$, we can see that $\frac{\partial X}{\partial \mu}<0$ and $\frac{\partial X}{\partial \sigma}>0$. Furthermore, $\frac{\partial C R S}{\partial X}>0$. Therefore, the higher the volatility of the international price, the larger the spread and the lower the growth rate of the international price, the lower the currency risk.
} 
We assume that the government wishes to maximize its wealth. Government wealth depends positively on tax revenues, the public investment returns, the reduction in debt payments from devaluation, and negatively on the costs of devaluation and debt payments. The floating policy will be defined by a boundary level for the international price such that the government floats the currency that maximizes sovereign wealth. Taking first-order conditions with respect to the international price, we obtain:

$$
\frac{\partial W}{\partial P}=\tau \frac{y}{\rho-\mu}-\frac{X \tau \lambda y}{\rho-\mu}\left(\frac{P_{t}}{P^{F}}\right)^{X-1}-\frac{C}{\rho} \frac{S-1}{S}\left(\frac{r_{g}}{\rho}-1\right) \frac{X}{P^{F}}\left(\frac{P_{t}}{P^{F}}\right)^{X-1}
$$

Using the smooth-pasting condition:

$$
\frac{\partial W}{\partial P}_{P=P^{F}}=\frac{\tau y}{\rho-\mu}(1-\lambda),{ }^{18}
$$

we obtain:

$$
P^{F}=C \frac{\frac{S-1}{S}\left(\frac{r_{g}}{\rho}-1\right) X(\rho-\mu)}{\lambda \tau y \rho(1-X)} .
$$

Note that the export-price lower bound before a country floats its currency, $P^{F}$, depends only on parameters. ${ }^{19}$ Figure 1 shows that $P^{F}$ depends positively on the risk free rate, $\rho$, and the currency devaluation, $S . P^{F}$ depends negatively on the return to public debt, $r_{g}$, the tax rate, $\tau$, the growth rate of export prices, $\mu$, the volatility of the export price, $\sigma$ and the output cost after leaving the peg, $\lambda$.

\footnotetext{
${ }^{18}$ This condition ensures continuity in the value of wealth at the time of devaluation.

${ }^{19}$ We take the coupon, $C$, and debt level, $D$, as given for simplicity, but we can easily solve for the country's debt capacity and coupon by maximizing the wealth of the country gross of the market value of debt.
} 

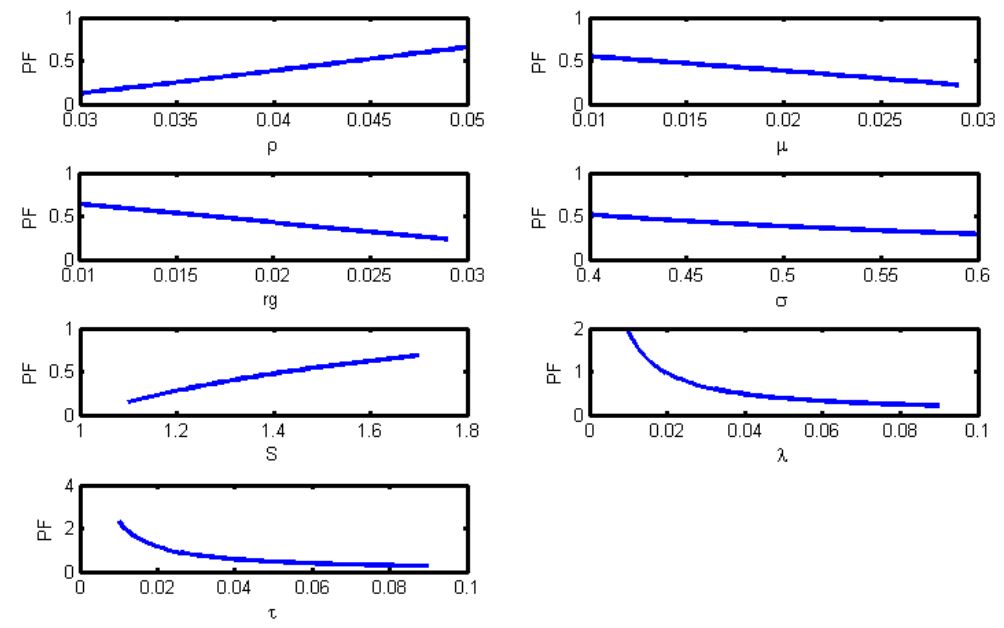

Figure 1: Comparative Statics for export-price lower bound: $\rho$ is risk free rate, $r_{g}$ is return on public spending financed with debt, $S$ is post-float currency devaluation, $\tau$ is tax rate, $\mu$ is the growth rate in principal-commodity price, $\sigma$ is volatility of principal-commodity price and $\lambda$ is the reduction in exports after devaluation.

Intuitively, anything that makes the post-devaluation worse, for example, higher output costs, is associated with lower $P^{F}$ and a lower probability of devaluing. Anything that improves the government's situation following devaluation, for example, a higher devaluation rate $S$, increases $P^{F}$, and implies a higher probability of devaluing.

\section{Empirical Analysis}

We turn now to testing empirically whether export prices have a causal impact on currency risk, using both structural and reduced-form models. 


\subsection{Data and descriptive statistics}

We employ a new high-frequency data set, from the classical gold standard period, to study the impact of international-price fluctuations on currency risk. We use weekly data on short-term interest rates to obtain monthly currency risk spreads as in Mitchener and Weidenmier (2015). Currency risk spreads are defined as a country's short-term open market or bank rate, denominated in domestic currency, minus the short-term gold denominated domestic UK trade bill. These three-month, prime-quality trade bills are very liquid and not subject to default risk. ${ }^{20}$ We combine these data with newly collected monthly data on the prices of internationally-traded goods from the Economist, as well as with information on the principal exports and imports for each of the countries in our sample. ${ }^{21}$

To identify the principal exports for each economy, we computed export weights from data gathered by the British Board of Trade (various years), Jacobson (1909), Mitchell (1982), Mitchell (2007a), and Mitchell (2007b). The first two publications provide detailed information on exports and imports by product for most of the countries in our sample between 1870 and 1909. Appendix B provides detailed information on the sources and the method used to determine the principal export for each country. ${ }^{22}$

The sample includes 21 economies and 8901 country-month observations span-

\footnotetext{
${ }^{20}$ See Neal and Weidenmier (2003) and Mitchener and Weidenmier (2015) for further details on the data.

${ }^{21}$ We use end of the month observations for all variables. To maximize coverage, when the end of the month observation is missing for currency risk we opt to use the first weekly observation of the following month (769 observations). If that is also not available, we use the average of the current month (13 observations). Argentina (190 observations), Greece (294 observations) and Japan (268 observations) account for most of these instances.

${ }^{22}$ Although one of our economies is a colony (India), and another a Grand-Duchy (Finland), we will use the words country and economy interchangeably to facilitate exposition.
} 
ning January 1870 - December 1913. Table 1 summarizes the data while Table 2 reports the three principal exports of each country, with the goods rank-ordered by their export share. As is common for the literature on the gold standard, Table 2 also denotes whether an economy is designated as part of the "core" or the "periphery". Following Bordo and Flandreau (2003), we use a country's capital importer/exporter status and its standard of living (measured by GDP/capita) to assign countries to one of these two groups.

\begin{tabular}{lccccc}
\hline Variable & Obs & Mean & Std. Dev. & Min & Max \\
\hline Month-year & 8901 & & & $1870 \mathrm{~m} 1$ & $1913 \mathrm{~m} 12$ \\
Currency risk & 8901 & $1.96 \%$ & $2.18 \%$ & $-3.12 \%$ & $13 \%$ \\
Export-Price index & 8901 & 92.6 & 24.3 & 44.4 & 211.2 \\
Export-Price index yearly growth & 8748 & $1.07 \%$ & $14.7 \%$ & $-50 \%$ & $150 \%$ \\
\hline
\end{tabular}

Table 1: Summary Statistics for monthly data

Empirically testing the effects of international price shocks on currency risk requires some further consideration of some of the model assumptions, in particular, as they relate to what is exported and who exports it. First, there is substantial variation in the principal export in different countries, but some exports are manufactured goods and not commodities. Second, commodities are more important for countries in the periphery. Economies in the core have more diversified production structures, including substantial shares of manufactures or semi-manufactures. These two facts suggest that the proposed mechanism identified in the model may operate more strongly in the periphery. Exogeneity of export-price movements is also more plausible in the periphery since specialization is largely determined by endowments, and these are in turn driven by exogenous factors such as climate and geography. To account for this heterogeneity, we allow estimated coefficients 


\begin{tabular}{|c|c|c|c|c|}
\hline Country & Principal Exports & $\operatorname{Max}(\%)$ & Core & Periphery \\
\hline Argentina & Wool, Wheat, Beef & 50 & & $\mathrm{X}$ \\
\hline Austria-Hungary & Timber, Sugar, Flour & 23 & & $\mathrm{X}$ \\
\hline Belgium & Flour, Coal, Iron & 15 & $\mathrm{X}$ & \\
\hline Bulgaria & Wheat, Barley, Animals & 82 & & $\mathrm{X}$ \\
\hline Chile & Nitrate, Copper, Coal & 81 & & $\mathrm{X}$ \\
\hline Denmark & Butter, Flour, Beef & 65 & & $\mathrm{X}$ \\
\hline Finland & Timber, Tar, Pitch & $\mathrm{N} / \mathrm{A}$ & & $\mathrm{X}$ \\
\hline France & Wool mf., Silk mf., Cotton mf. & 15 & $\mathrm{X}$ & \\
\hline Germany & Iron prod., Wool mf., Flour & 15 & $\mathrm{X}$ & \\
\hline Greece & Iron, Olive oil, lead & 30 & & $\mathrm{X}$ \\
\hline India & Cotton, Rice, Tea & 49 & & $\mathrm{X}$ \\
\hline Italy & Silk, Olive oil, Hemp & 49 & & $\mathrm{X}$ \\
\hline Japan & Silk, Tea, Rice & 60 & & $\mathrm{X}$ \\
\hline Mexico & Silver, Coffee, Copper & 84 & & $\mathrm{X}$ \\
\hline Netherlands & Drugs, Flour, Iron prod. & 22 & $\mathrm{X}$ & \\
\hline Norway & Timber, Iron, Oats & 52 & & $\mathrm{X}$ \\
\hline Romania & Wheat, Barley, Flax & 59 & & $\mathrm{X}$ \\
\hline Russia & Wheat, Flax, Barley & 31 & & $\mathrm{X}$ \\
\hline Sweden & Timber, Iron, Oats & 49 & & $\mathrm{X}$ \\
\hline Switzerland & Cotton mf., Silk, Timber & 24 & $\mathrm{X}$ & \\
\hline USA & Cotton, Wheat, Beef & 34 & $\mathrm{X}$ & \\
\hline
\end{tabular}

Table 2: Table of countries and principal exports, rank-ordered by share of an economy's total exports. Max (\%) represents maximum share of principal-export weight for a particular year between 1880 - 1913, mf. stands for manufactures. Principal exports used in baseline regression specifications are identified in bold. For some economies the price of the principal export is not available at a monthly level. Appendix B reports all the sources and methods used to determine the principal exogenous exports and price series. A country is defined as part of the core if it had an average real GDP per capita equal or larger than 2500 international GK 1990 dollars between 1870 - 1913 (data from the Maddison Project, 2013 version), and is a capital exporter (the exception to this rule is the USA, which was a capital importer until 1900. Denmark and Argentina both exceed the income threshold but are capital importers for most of our sample.). 
to differ across the core and the periphery in our empirical specifications. Finally, note that a few countries had near monopolies in the production of some goods. ${ }^{23}$

The mechanism explored in the model works through domestically-denominated debt. Although we do not have data on the proportion of debt denominated in domestic currency for all our 21 economies, Accominotti et al. (2011) reports that a substantial share of foreign public debt was in fact denominated in domestic currency, including in some economies in the periphery. ${ }^{24}$

To illustrate the mechanism, Figure 2 plots currency risk (solid line) against the growth rate in the price of Chile's principal exports, nitrate (dashed line) and copper (dotted line). Consistent with the model, we can see from this figure that Chile's currency risk is negatively correlated with the growth rate of the international price of copper: the correlation coefficient is -0.17 and significantly different from zero at the $1 \%$ level. $^{25}$ Turning to our sample of 21 economies, the correlation between currency risk and the yearly growth in the price of the

\footnotetext{
${ }^{23}$ Two noteworthy cases are Chile for nitrate and the Netherlands for quinine (Peruvian bark grown in Java.). We do not have monthly prices for Peruvian bark, and use the Netherlands' second largest export instead. Note that the Netherlands pose an additional challenge related to the fact that most of their exports are also imports going through its harbors. We address the issue of monopoly power and re-exporting in a specification where we replace nitrate with copper for Chile, and where we drop the Netherlands from our sample of countries.

${ }^{24} \mathrm{We}$ refer the reader to the Global Finance database, available online at http://eh.net/database/global-finance/, for further details on these data, in particular, the series "Share of foreign debt serviced in gold or gold currency (\%)". See also Bordo and Meissner (2006) for an analysis of the incidence of original sin in the periphery. The reduction of the real value of government-debt payments is related to the literature on the "Twin D's": default and devaluation (Calvo, 1988; Aguiar et al. (2013); Corsetti and Dedola (2016); Na et al. (2014)). Even though we focus on the reduction of real debt payments, it should be noted that there are other potential sources of inflation-related revenues, such as seigniorage and the reduction of real payments of nominal government contracts (e.g., public wages). See Burnside et al. (2001) and Burnside et al. (2006) for theoretical and empirical analysis of these alternative mechanisms in the late 1990s Asian Crisis.

${ }^{25}$ Although copper is not Chile's principal export, it is more exogenous than Chile's most important commodity export at the time, nitrate. The unconditional correlation coefficient between currency risk and the growth rate of the price of nitrate is 0.02 , and not significantly different from zero between 1870 and 1913.
} 
principal export is -0.05 and significantly different from zero at the $1 \%$ level. The correlation between currency risk and the price of the second main export is -0.04 and significantly different from zero at the $1 \%$ level.

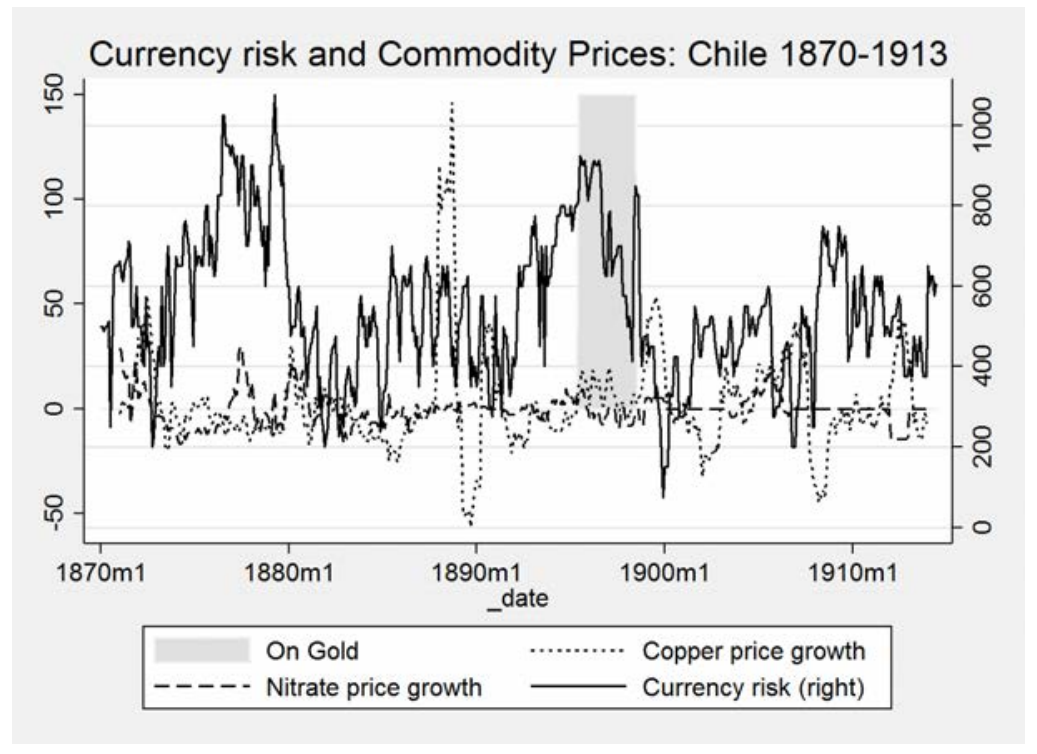

Figure 2: Currency risk (solid line on right axis) and yearly export-price growth for copper (dotted line on left axis) and nitrate (dashed line on left axis) for Chile.

Chile's abandonment of gold in the 1890s, one of the few exits from a hard peg during the classical gold standard era, shows how negative export-price shocks contribute to the breaking of a peg and how this is captured by measured currency risk. Chile had rejoined the gold standard on June 1, 1895, only to abandon it three years later in July 1898. In this period, Chile suffered a number of negative shocks, including a border dispute with Argentina that resulted in an arms race and an increased defense budget; however, Collier and Sater (1996) stress the role of export-price shocks in making a bad situation worse. 


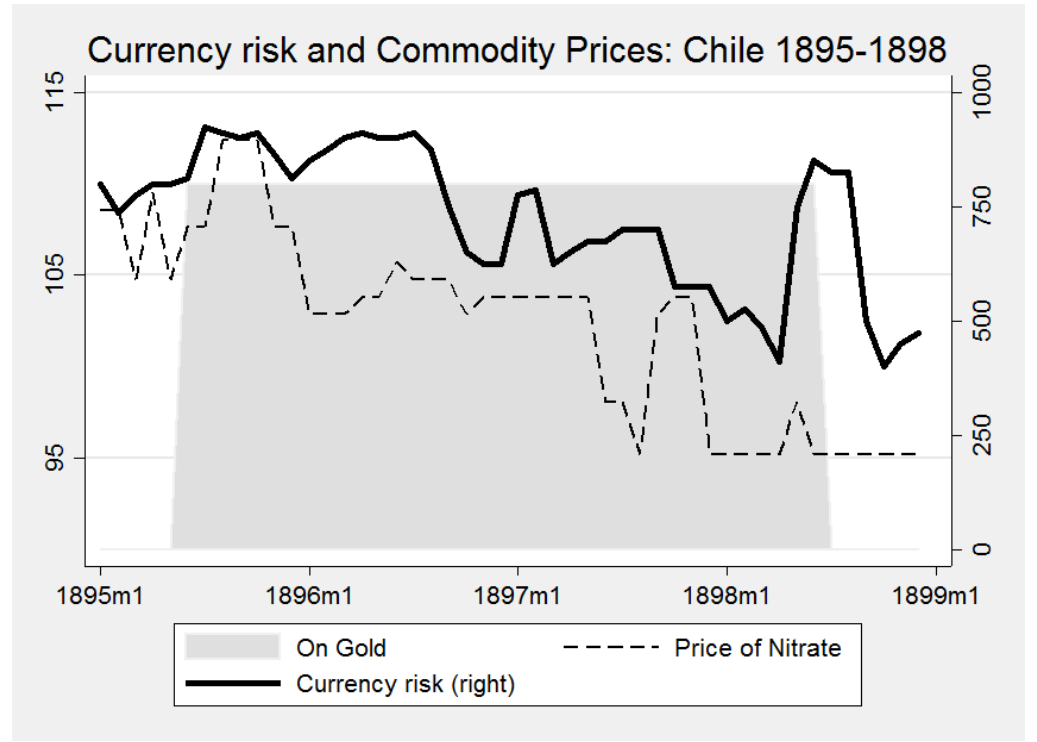

Figure 3: Currency risk (solid line on right axis, measured in basis points), Nitrate price index (dashed line on left axis, average $1913=100$ ). Adherence to gold (shaded area) is also plotted.

Figure 3 plots our measure of currency risk (solid line) together with the price index for nitrate, Chile's most important export by value. Chile's adherence to the gold standard is also plotted. Between June 1895 and July 1898, we can see that the price of nitrate fell by $11.5 \%$. The price of copper, Chile's second most important export, also decreased 3\% between May 1898 and July 1898. Unsurprisingly, currency risk peaked just as Chile abandoned gold, while its exchange rate devalued from 13.64 pesos per pound between $1897-1898$ to 16.55 pesos per pound in 1899 .

\section{$3.2 \quad$ Structural analysis}

In this section we investigate if currency risk is related to the price of exports using a specification derived directly from our theoretical model. Our model es- 
tablished that, everything else equal, permanent, negative price shocks increase currency risk, while permanent, positive price shocks decrease currency risk. The structural specification can be obtained by taking a first-order Taylor approximation of equation (10):

$$
C R S_{t}\left(P_{t}\right)=\frac{\rho \frac{S-1}{S}\left(\frac{P_{t}}{P^{F}}\right)^{X}}{1-\frac{S-1}{S}\left(\frac{P_{t}}{P^{F}}\right)^{X}} \approx \rho \frac{S-1}{S}\left(\frac{P_{t}}{P^{F}}\right)^{X}
$$

when $C R S$ is relatively small. ${ }^{26}$ This equation can then be estimated for each country using non-linear least squares:

$$
C R S_{t}=\alpha P_{t}^{X}+\epsilon_{t}
$$

where $t$ stands for month-year, $\alpha=\rho \frac{S-1}{S}\left(P^{F}\right)^{-X}$ and, according to the theoretical model, $X<0 .{ }^{27}$

In our baseline specifications, we report results using the raw data instead of extracting permanent components of prices. This approach is conservative in the sense that any bias goes against finding a relationship between export prices and currency risk. Moreover, it is relatively more transparent than transforming the

\footnotetext{
${ }^{26}$ We opt for the first order approximation instead of estimating equation (10) directly due to the discontinuity in this equation when the denominator approaches zero.

${ }^{27}$ In the model we assumed that after a country leaves the peg, its currency devalues. For some countries measured currency risk is occasionally slightly negative which in the model would be consistent with an expected appreciation of the currency following an exit. In other words, our coefficient $\alpha$ would change sign. This coefficient instability poses a challenge for our estimation in countries with a higher proportion of negative currency risk. Countries in our core are more likely to experience negative currency risk: France (282 observations), Belgium (213), Netherlands (210), Germany (194). Countries with 51-100 observations of negative currency risk: Switzerland, Norway, Austria-Hungary, United States and Denmark; Countries with 1-50 observations of negative currency risk: Finland, India, Italy, Romania, Russia, Sweden.
} 
data. $^{28}$

Table 3 collects the estimated parameter $X$ for each country, together with its robust standard error. Countries are rank-ordered by the magnitude of this coefficient, which according to the model, should be smaller than zero. We can see that for most countries in our sample, and especially for those located in the periphery, this coefficient is indeed smaller than zero and, particularly for countries in the periphery, statistically different from zero. ${ }^{29}$

Although this exercise confirms a crucial result from the model, it does not take into account omitted variables affecting all countries simultaneously, or whether having a formal commitment to gold plays a role. To investigate these issues, we obtain a linear specification by applying logs to both sides of equation (15):

$$
\log \left(C R S_{c, t}\right) \approx \log (\rho)+\log \left(\frac{S_{c}-1}{S_{c}}\right)+X_{c} \log \left(P_{c, t}\right)-X_{c} \log \left(P_{c}^{F}\right)
$$

where $c$ corresponds to country, $t$ stands for month-year, $\rho$ is the risk free rate, $\frac{S_{c}-1}{S_{c}}$ captures country-specific devaluation following the peg, $P_{c, t}$ captures the price of the main export and $P_{c}^{F}$ captures the country-specific price of exports at which the government floats the currency. Assuming that $\rho, X$ and $P^{F}$ are time-invariant, as in the model, this equation can be estimated on our full panel of countries as:

\footnotetext{
${ }^{28}$ In our theoretical model we assume that export-price growth follows a random walk, which has a unit root. We discuss this and other issues associated with non-stationary of our data in Section 4.

${ }^{29}$ The coefficient $X$ for France stands out as a clear outlier. Most of France's currency risk observations are of negative currency risk. Performing a sample split for France on this dimension, we obtain that this coefficient is 0.08 for positive currency risk observations (115), and 0.7 for negative currency risk observations (282). Estimated $\alpha$ coefficients are positive throughout, with the exception of France, when currency risk is negative, and Belgium.
} 


\begin{tabular}{llcc}
\hline \hline Country & $X$ coefficient & Robust Standard Error & Core \\
\hline France & $3.33^{* * *}$ & 0.45 & $\mathrm{X}$ \\
USA & $0.78^{* * *}$ & 0.30 & $\mathrm{X}$ \\
Bulgaria & $0.21^{* * *}$ & 0.08 & \\
Italy & 0.11 & 0.27 & \\
Chile & 0.02 & 0.10 & \\
Russia & 0.01 & 0.10 & \\
Mexico & -0.09 & 0.33 & $\mathrm{X}$ \\
Netherlands & -0.12 & 1.53 & $\mathrm{X}$ \\
Belgium & -0.24 & 1.49 & $\mathrm{X}$ \\
Germany & -0.46 & 0.72 & \\
Norway & $-0.55^{* * *}$ & 0.20 & \\
Denmark & $-0.74^{* * *}$ & 0.26 & \\
Finland & $-0.76^{* * *}$ & 0.19 & \\
Japan & $-0.96^{* * *}$ & 0.15 & \\
Sweden & $-1.04^{* * *}$ & 0.18 & \\
Argentina & $-1.32^{* * *}$ & 0.06 & \\
Romania & $-1.40^{* * *}$ & 0.12 & \\
Greece & $-1.45^{* * *}$ & 0.10 & \\
India & $-1.68^{* * *}$ & 0.36 & \\
Austria-Hungary & $-1.94^{* * *}$ & 0.26 & \\
Switzerland & $-2.65^{* * *}$ & 0.46 & \\
\hline \hline
\end{tabular}

Table 3: Country-by-country regression of $C R S_{t}$ on the principal-export price using non-linear least squares as defined in equation (16). Coefficient $\alpha$ not reported. $* * * \mathrm{p}<0.01,{ }^{*} * \mathrm{p}<0.05,{ }^{*} \mathrm{p}<0.1$. 


$$
\log \left(C R S_{c, t}\right)=\alpha+\gamma_{c}+\beta \log \left(P_{c, t}\right)+\epsilon_{c, t},
$$

where the country fixed effect $\gamma_{c}$ captures all the time-invariant country and product-specific factors. ${ }^{30}$

For some countries, in particular those in the core, measured currency risk is occasionally slightly negative. Applying logs would yield in a number of missing observations (1677 of 8901). Thus, in our main structural panel specification, we follow Burbidge et al. (1988) and take the inverse hyperbolic sine of currency risk:

$$
H\left(C R S_{c, t}\right)=\frac{\log \left[\theta C R S_{c, t}+\left(\theta^{2} C R S_{c, t}^{2}+1\right)^{0.5}\right]}{\theta},
$$

where $\theta=1 .{ }^{31}$ Unlike the $\log$, this transformed variable is also defined at zero and at negative values. With the exception of values close to zero, it is approximately equal to $\log \left(2 C R S_{c, t}\right)$ and can be interpreted similarly as the log. Alternative ways of dealing with negative observations, such as, adding a constant to the currency risk premia so that it is always positive, or truncating the data to observations for which currency risk is greater than zero, both yield similar estimates.

Table 4 collects the results of estimating the specification given by equation (18), adding year fixed effects. All regressions include country fixed effects and have standard errors clustered at the country level. Column (1) of Table 4 shows the coefficients of the regression of currency risk on export prices, when we absorb exclusively time-invariant country fixed effects. Looking at column (1) of Table 4,

\footnotetext{
${ }^{30}$ Note that the model implies that our slopes $\beta$ are country specific. Wooldridge (2005) shows that traditional country fixed-effects methods can be used to estimate the population-averaged $\beta$, even if slopes are country-specific and correlated with covariates.

${ }^{31} \theta$ is a dampening parameter and results are robust to using alternative values for $\theta$. See Carroll et al. (2003) for an application in the household finance literature and further discussion.
} 
we can see that, on average, when a country's principal-export price decreases by $10 \%$, currency risk rises by $5.6 \%$. This effect is significantly different from zero at the $1 \%$ level, but reduced in magnitude when controlling for year fixed effects. ${ }^{32}$ Specifications in columns (3)-(6) include year fixed effects and allow the $\beta$ coefficient to differ depending on whether an economy is part of the core or periphery. As noted above, this latter distinction is potentially important because the peripheral countries have less diversified production structures and are also more likely to be price-takers in world markets. Column (3) thus shows interactions between the price of the principal export and a dummy variable that takes the value of 1 if the country is in the core, and zero otherwise, such that the coefficient on the export price alone captures our coefficient of interest for the periphery. As expected, the coefficient of interest is negative for the periphery but not for the core countries. In particular, we find that a $10 \%$ decrease in the price index of the principal export in the periphery causes an increase of $2.8 \%$ in currency risk spreads.

Since our model examines currency risk from the perspective of abandoning a peg, column (4) explicitly takes this into account by interacting export prices with a dummy variable capturing the period when a country was adhering to the gold standard. ${ }^{33}$ For the periphery, it is possible to see that formally pegging to gold makes the causal impact of prices stronger, as the coefficient $\beta$ is further reduced. In columns (5) and (6), we perform our regression on two sub-samples, in and out

\footnotetext{
${ }^{32}$ We obtain effects of similar magnitude if we censor observations to be positive (5\%), or if we add a constant to all currency risk spreads, such that they are always positive $(2.6 \%)$.

${ }^{33}$ If there are some benefits to smoothing exchange rates, a similar mechanism to the one we modeled may also operate outside of a formal currency peg. In particular, note that countries can shadow the gold standard even if they do not explicitly adopt it. Dates of gold-standard adherence are collected in Table 11.
} 


\begin{tabular}{|c|c|c|c|c|c|c|}
\hline & (1) & $(2)$ & $(3)$ & (4) & $(5)$ & (6) \\
\hline Export price & $\begin{array}{c}-0.56^{* * *} \\
(0.16)\end{array}$ & $\begin{array}{l}-0.12 \\
(0.14)\end{array}$ & $\begin{array}{c}-0.28^{*} \\
(0.15)\end{array}$ & $\begin{array}{l}-0.27 \\
(0.19)\end{array}$ & $\begin{array}{c}\text { On Gold } \\
-0.30 \\
(0.18)\end{array}$ & $\begin{array}{c}\text { Not on Gold } \\
-0.32^{*} \\
(0.16)\end{array}$ \\
\hline Export price $\mathrm{x}$ Core & & & $\begin{array}{c}0.66^{* *} \\
(0.27)\end{array}$ & $\begin{array}{c}1.50 * * * \\
(0.26)\end{array}$ & $\begin{array}{c}0.74^{* *} \\
(0.29)\end{array}$ & $\begin{array}{c}1.36^{* * *} \\
(0.35)\end{array}$ \\
\hline Gold & & & & $\begin{array}{c}0.27 \\
(0.68)\end{array}$ & & \\
\hline Export price x Gold & & & & $\begin{array}{l}-0.03 \\
(0.16)\end{array}$ & & \\
\hline Core x Gold & & & & $\begin{array}{c}3.85^{* * *} \\
(1.27)\end{array}$ & & \\
\hline Export price x Core x Gold & & & & $\begin{array}{c}-0.84^{* * *} \\
(0.28)\end{array}$ & & \\
\hline Year fixed effects & & $\mathrm{X}$ & $\mathrm{X}$ & $\mathrm{X}$ & $\mathrm{X}$ & $\mathrm{X}$ \\
\hline Constant & $\begin{array}{c}3.60^{* * *} \\
(0.72)\end{array}$ & $\begin{array}{c}0.94 \\
(0.81)\end{array}$ & $\begin{array}{c}0.83 \\
(0.82)\end{array}$ & $\begin{array}{l}-0.32 \\
(1.01)\end{array}$ & $\begin{array}{c}0.62 \\
(0.78)\end{array}$ & $\begin{array}{c}2.49^{* * * *} \\
(0.78)\end{array}$ \\
\hline Observations & 8,901 & 8,901 & 8,901 & 8,901 & 5,926 & 2,975 \\
\hline Adjusted R-squared & 0.024 & 0.21 & 0.22 & 0.22 & 0.22 & 0.25 \\
\hline Number of countries & 21 & 21 & 21 & 21 & 21 & 16 \\
\hline
\end{tabular}

Table 4: Regression of $H\left(C R S_{c, t}\right)$ on the $\log$ of principal-export price, where $H\left(C R S_{c, t}\right)$ is defined in equation (19). Core takes on a value of 1 for the core countries, zero otherwise. Gold takes on a value of 1 if the country has a formal gold commitment in place, zero otherwise. $\mathrm{x}$ represents interaction. ${ }^{* * *} \mathrm{p}<0.01$, $* *$ $\mathrm{p}<0.05,{ }^{*} \mathrm{p}<0.1$. Robust standard errors in parentheses clustered at the country level.

of gold. We can see that the effect for peripheral countries is of similar magnitude across samples.

Our theoretical model highlights the role of export-price shocks in determining currency risk, and the corresponding empirical estimates confirm the main prediction of the model. That said, currency traders of the late $19^{\text {th }}$ century may have factored in other country-specific, time-varying factors when assessing the durability of gold standard pegs that are not captured in the empirical estimates of the structural model. Furthermore, the structural estimation assumes that export 
price shocks are permanent, which may not necessarily be the case. To investigate these issues further, in the next subsection we explore a reduced-form empirical approach to study the relationship between export prices and currency risk.

\subsection{Reduced form analysis}

Our reduced form empirical model can be specified according to the following equation:

$$
C R S_{c, t}=\alpha+\phi_{t}+\mu_{c}+\beta X_{c, t}+\gamma Z_{c, t}+\epsilon_{c, t}
$$

where $C R S_{c, t}$ represents currency risk spreads, $c$ corresponds to country, $t$ stands for month-year, $\phi_{t}$ captures time fixed effects, $\mu_{c}$ summarizes country fixed effects, $X_{c, t}$ refers to measures of the price of the principal export, and finally $Z_{c, t}$ contains country controls that vary monthly or annually. We test if $\beta$ is less than zero, which according to the model, would suggest a negative relationship between export prices and currency risk. In our baseline specification, we begin by examining the annual movements in currency risk and export prices and regress currency risk on the annual growth rate in the price of the principal export. ${ }^{34}$

Table 5 reports the coefficients of regressions of average currency risk at year $y$ (measured in basis points) on the annual growth rate of the average export price in the same year $y$ and measured in percentage points. Column (1) shows that the average effect across countries is negative but small, and not statistically different

\footnotetext{
${ }^{34}$ The yearly growth rate of export prices has been used in applied research that explores variation from exogenous commodity prices (See, for example, Bazzi and Blattman (2014) and Caselli and Tesei (2016)). Furthermore, it makes less restrictive assumptions on the permanent nature of export price shocks. One-month fluctuations in the level of export prices may not be sufficient to affect currency risk in the market, perhaps because they are the consequence of other temporary shocks; one-year growth rates are more likely to capture permanent changes in prices.
} 
from zero. On the other hand, once we introduce the core-periphery distinction in our sample, column (2) shows that a 10 percentage point decrease in the growth rate of the price of the principal export of a country in the periphery is associated with an increase of average currency risk of about 10 basis points. This effect is also present when we consider one-year lagged growth in prices as in column (3), and it is magnified when controlling for past growth in export prices as demonstrated in columns (4) and (5). ${ }^{35}$

Although there are reasons one might prefer the annual estimates, Table 6 reports on similar specifications, but using changes in monthly prices of principal exports. We regress the level of currency risk on the one year percent change in prices, both measured at the end of the month. As shown in columns (1) and (2), the coefficient of interest for the periphery remains negative and statistically different from zero at least at the $10 \%$ level. As discussed above, we are also interested on whether the mechanism is stronger with or without a currency peg. In column (3), we allow for interactions between gold, core and the price of export. For the periphery, it is possible to see that adhering to gold increases the causal impact of prices on currency risk since the coefficient on export prices interacted with gold is also negative. Summing the coefficients for price growth and price growth interacted with gold in the periphery, we obtain a coefficient of -0.68 , which is significantly different from zero at the $1 \%$ level according to a joint significance test. This coefficient implies that, on average, a one standard deviation in the

\footnotetext{
${ }^{35}$ If we do not control for year fixed effects, the effect size is even larger, up to 24 basis points following a 10 percentage point decrease in the growth rate of the principal-export price. Note that our measure of currency risk is relative to the UK short-term open market rate, such that any common shocks affecting the UK and the countries in our sample are already captured without year fixed effects. In this context, year fixed effects capture any common shocks to all countries, except the UK.
} 


\begin{tabular}{|c|c|c|c|c|c|}
\hline & (1) & (2) & 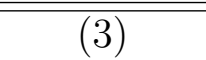 & 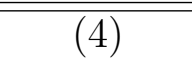 & $(5)$ \\
\hline Export-price growth & $\begin{array}{l}-0.33 \\
(0.32)\end{array}$ & $\begin{array}{c}-0.96^{* * *} \\
(0.30)\end{array}$ & & $\begin{array}{c}-1.04^{* * *} \\
(0.30)\end{array}$ & $\begin{array}{c}-1.16^{* * *} \\
(0.28)\end{array}$ \\
\hline Export-price growth $\mathrm{x}$ Core & & $\begin{array}{c}1.83^{* * *} \\
(0.50)\end{array}$ & & $\begin{array}{c}1.91^{* * *} \\
(0.51)\end{array}$ & $\begin{array}{c}2.24^{* * *} \\
(0.44)\end{array}$ \\
\hline Export-price growth $_{y-1}$ & & & $\begin{array}{c}-0.85^{* *} \\
(0.32)\end{array}$ & $\begin{array}{c}-0.86^{* *} \\
(0.32)\end{array}$ & $\begin{array}{c}-1.00^{* *} \\
(0.40)\end{array}$ \\
\hline Export-price growth gr-1 $\#$ Core & & & $\begin{array}{l}1.07^{* *} \\
(0.51)\end{array}$ & $\begin{array}{l}1.03^{* *} \\
(0.47)\end{array}$ & $\begin{array}{c}1.53^{* * *} \\
(0.41)\end{array}$ \\
\hline Export-price growth $_{y-2}$ & & & & & $\begin{array}{l}-0.45 \\
(0.44)\end{array}$ \\
\hline Export-price growth ${ }_{y-2} \#$ Core & & & & & $\begin{array}{l}0.99 * \\
(0.55)\end{array}$ \\
\hline Export-price growth $_{y-3}$ & & & & & $\begin{array}{l}-0.33 \\
(0.32)\end{array}$ \\
\hline Export-price growth gr-3 $_{3} \#$ Core & & & & & $\begin{array}{l}1.69^{* *} \\
(0.67)\end{array}$ \\
\hline Year fixed effects & $\mathrm{X}$ & $\mathrm{X}$ & $\mathrm{X}$ & $\mathrm{X}$ & $\mathrm{X}$ \\
\hline Constant & $\begin{array}{c}106.59^{* * *} \\
(31.86)\end{array}$ & $\begin{array}{c}98.90 * * * \\
(31.74)\end{array}$ & $\begin{array}{c}353.65^{* * *} \\
(33.74)\end{array}$ & $\begin{array}{c}358.48^{* * *} \\
(32.89)\end{array}$ & $\begin{array}{c}364.74^{* * *} \\
(31.51)\end{array}$ \\
\hline Observations & 741 & 741 & 729 & 729 & 704 \\
\hline Adjusted R-squared & 0.44 & 0.45 & 0.45 & 0.46 & 0.46 \\
\hline Number of countries & 21 & 21 & 21 & 21 & 21 \\
\hline
\end{tabular}

Table 5: Regression of average currency risk at year $y$ (measured in basis points) on the annual growth rate of the average export price at year $y$. Core takes on a value of 1 for the core countries, zero otherwise. $\mathrm{x}$ represents interaction. *** $\mathrm{p}<0.01,{ }^{* *} \mathrm{p}<0.05,{ }^{*} \mathrm{p}<0.1$. Robust standard errors in parentheses clustered at the country level. 


\begin{tabular}{|c|c|c|c|c|c|}
\hline & $(1)$ & $(2)$ & $(3)$ & $(4)$ & $(5)$ \\
\hline Export-price growth & $\begin{array}{c}-0.80^{* *} \\
(0.38)\end{array}$ & $\begin{array}{l}-0.44^{*} \\
(0.24)\end{array}$ & $\begin{array}{l}-0.19 \\
(0.40)\end{array}$ & $\begin{array}{c}\text { On Gold } \\
-0.54^{* * *} \\
(0.19)\end{array}$ & $\begin{array}{c}\text { Not on Gold } \\
-0.08 \\
(0.41)\end{array}$ \\
\hline Export-price growth x Core & $\begin{array}{c}0.52 \\
(0.44)\end{array}$ & $\begin{array}{l}1.03^{* *} \\
(0.39)\end{array}$ & $\begin{array}{c}0.78 \\
(0.63)\end{array}$ & $\begin{array}{c}1.05^{* * * *} \\
(0.34)\end{array}$ & $\begin{array}{c}0.31 \\
(0.72)\end{array}$ \\
\hline Gold & & & $\begin{array}{c}-1.68 \\
(21.31)\end{array}$ & & \\
\hline Export-price growth x Gold & & & $\begin{array}{l}-0.49 \\
(0.38)\end{array}$ & & \\
\hline Core x Gold & & & $\begin{array}{c}22.98 \\
(31.15)\end{array}$ & & \\
\hline Export-price growth x Core x Gold & & & $\begin{array}{c}0.48 \\
(0.56)\end{array}$ & & \\
\hline Year fixed effects & & $\mathrm{X}$ & $\mathrm{X}$ & $\mathrm{X}$ & $\mathrm{X}$ \\
\hline Constant & $\begin{array}{c}197.20^{* * *} \\
(0.31)\end{array}$ & $\begin{array}{c}88.18^{* * *} \\
(26.96)\end{array}$ & $\begin{array}{c}81.05^{* * *} \\
(26.44)\end{array}$ & $\begin{array}{c}114.27^{* * *} \\
(3.75)\end{array}$ & $\begin{array}{c}326.71^{* * *} \\
(10.22)\end{array}$ \\
\hline Observations & 8,748 & 8,748 & 8,748 & 5,878 & 2,870 \\
\hline Adjusted R-squared & 0.01 & 0.27 & 0.27 & 0.23 & 0.31 \\
\hline Number of countries & 21 & 21 & 21 & 21 & 16 \\
\hline
\end{tabular}

Table 6: Regression of the level of currency risk (measured in basis points) on the yearly growth rate of the principal-export monthly price. Core takes on a value of 1 for the core countries, zero otherwise. Gold takes on a value of 1 if the country has a formal gold commitment in place, zero otherwise. $\mathrm{x}$ represents interaction. $* * * \mathrm{p}<0.01,{ }^{* *} \mathrm{p}<0.05,{ }^{*} \mathrm{p}<0.1$. Robust standard errors in parentheses clustered at the country level.

yearly growth of the price of the principal export (14.7\%), increases currency risk in the periphery, while adhering to gold, by about 10 basis points. In columns (4) and (5), we alternatively examine the sub-samples in and out of gold. They show that the effect of export prices is stronger when peripheral countries formally adhere to gold. 


\subsection{Discussion}

Our empirical analysis suggests a causal mechanism through which exogenous fluctuations of export prices affect currency risk. Our identifying assumptions are that: (i) countries specialize in different products due to pre-determined factor endowments and (ii) the prices of these products are determined in world markets and therefore exogenous to price-taking countries.

Although we find statistically significant estimates, the quantitative impact of export price changes on currency risk are relatively small. However, given our estimation strategy, this is not surprising for two reasons. First, our results capture the effect of the principal export on currency risk, but countries often export a range of products, and their relative importance can change over time. Since we hold the principal export fixed for every country in our sample, our estimates likely understate the the "true" effect. ${ }^{36}$ Second, we are not attempting to explain the cross-sectional variation of currency risk, which depends, among other things, on the constant mean and volatility of the export-price series, but instead identify the causal impact of realized export prices. We take a conservative approach that controls for country and year fixed effects together with standard errors clustered at the country level, and find that the principal-export price has a causal impact on currency risk, particularly for the periphery, as well as when countries formally adhered to gold.

\footnotetext{
${ }^{36}$ For example, as discussed in appendix B, although butter is the main export for Denmark in our full sample, before 1890 flour represented a larger share of Danish exports.
} 


\section{Extensions and robustness checks}

In this section, we extend our empirical analysis to consider the boom-bust nature of commodity prices, and report on a battery of robustness checks, including investigating the role of lagged effects and monthly growth rates, as well as additional country-specific covariates.

We follow the methodology in Jacks (2013) and identify whether a particular export is experiencing a price boom or bust using the Christiano and Fitzgerald (2003) band-pass filter. We decompose the time-series of export prices to extract the cyclical component and create monthly dummies to capture booms and busts in export prices. ${ }^{37}$ Table 7 collects the results for peripheral countries under the gold standard and shows that export-price booms are associated with decreases in currency risk while export-price busts are associated with increases in currency risk. These coefficients are larger than our baseline results, but in our regression with standard errors clustered at the country level, not very precisely estimated. ${ }^{38}$ Column (3) allows for the interaction of booms or busts in the two main exports. It shows that simultaneous busts in the prices of the two most important exports cause an increase in currency risk of 71 basis points, while simultaneous booms cause a decrease in currency risk of 44 basis points. An F-test for the joint significance of simultaneous bust events rejects that these are different from zero at the $5 \%$ statistical significance level, while we can not reject that simultaneous boom events have no impact on currency risk at standard levels of statistical

\footnotetext{
${ }^{37}$ We look at deviations from the medium-run cycle in logged prices for export, subtract sample mean of deviations and divide by their standard deviations, to obtain a standardized measure of short-run deviations. A boom is identified as a deviation that is above the threshold of the 10 $\%$ tail of a normal distribution, a bust has a symmetric definition.

${ }^{38}$ Coefficients for the core countries are small and not statistically different from zero.
} 
Principal-export price boom

Second-export price boom

Principal-export price boom x Second-export price boom

Principal-export price bust

Second-export price bust

Principal-export price bust $\mathrm{x}$ Second-export price bust

Constant

Observations

Adjusted R-squared

Number of countries
$-6.28$

$(17.87)$

$$
23.19^{* *}
$$

$-12.92$

$-9.37$

8.64

(12.46)

$-0.28$

(17.18)

62.92

(38.43)

$199.60 * * * \quad 202.76 * * *$ 203.65***

3,503

3,401

0.00

0.01

3,401

0.01

Table 7: Regression of the level of currency risk (measured in basis points) on dummy variables that capture booms and busts in export prices. Only periphery countries during the Gold Standard. ${ }^{* * *} \mathrm{p}<0.01$, ${ }^{* *} \mathrm{p}<0.05{ }^{*} \mathrm{p}<0.1$. Robust standard errors in parentheses clustered at the country level.

significance. $^{39}$

To understand how price shocks are transmitted into currency risk we exploit the time-series dimension in the data and regress currency risk spreads (measured in basis points) on the monthly growth rate of the principal-export price, including up to 12 lags. Results are reported in Table 8. Column (1) reports $\beta$ coefficients pooled for core and periphery while columns (2) and (3) allow the $\beta$ coefficient to be different between core and periphery (core coefficients not reported). Additionally, column (3) uses only observations for countries that are on the gold standard at

\footnotetext{
${ }^{39}$ There are some limited occurrences of booms in one main export, and busts in the other. Controlling for the full set of interactions does not change the results.
} 
time $t$. The main message of this table is that all the lagged monthly growth rates in export prices negatively impact currency risk levels at $t$. An F-test that these monthly growth rates are all equal to zero is rejected at the $1 \%$ level. These export-price effects are stronger when focusing on periphery countries, and even stronger when focusing on periphery countries that adhere to gold.

Table 9 reports similar regressions, but considers up to 6 lags and 6 leads. We can use these results to perform a simple falsification test since leads of the monthly growth of prices should not be related to past currency risk. Again, all the lag coefficients are negative. Some of the lead coefficients are initially negative, but turn zero after 3 months. Focusing on countries in the periphery that adhere to gold, we can see that lag coefficients are larger and more precisely estimated than lead coefficients, particularly for lags longer than 2 months, and that leads from 3 months onwards are not significantly different from zero. We find that, even after controlling for leads, lags of export-price growth have a causal impact on currency risk, while leads do not cause currency risk. These results are consistent with our theory and other empirical results for the relationship between export prices and currency risk. ${ }^{40}$

As a further robustness check, we augment our baseline model and include institutional variables, country-specific events and macroeconomics variables that may also be drivers of currency-risk spreads. Although some of these may be of interest in their own right, we see them as conditioning variables and do not take a stand on whether they are endogenous or exogenous. Crucially, if export prices

\footnotetext{
${ }^{40}$ The fact that lags and leads close to $t$ are of similar magnitude may indicate measurement error in the historical price series, auto-correlation on the monthly price growth series, or both. We see it as an additional reason to focus on yearly growth rates as we did in the baseline specifications outlined in Section 3.3 .
} 


\begin{tabular}{|c|c|c|c|}
\hline & $(1)$ & $(2)$ & $(3)$ \\
\hline \multirow{3}{*}{ Export-price growth $_{t}$} & Pooled & Core vs Periphery & Core vs Periphery on Gold \\
\hline & -0.04 & -0.35 & -0.39 \\
\hline & $(0.20)$ & $(0.26)$ & $(0.29)$ \\
\hline \multirow[t]{2}{*}{ Export-price growth $_{t-1}$} & -0.04 & -0.44 & -0.80 \\
\hline & $(0.35)$ & $(0.45)$ & $(0.53)$ \\
\hline \multirow[t]{2}{*}{ Export-price growth t-2 $_{t}$} & -0.25 & -0.63 & $-1.09^{*}$ \\
\hline & $(0.42)$ & $(0.54)$ & $(0.53)$ \\
\hline \multirow[t]{2}{*}{ Export-price growth $_{t-3}$} & -0.30 & -0.78 & $-1.31^{* *}$ \\
\hline & $(0.43)$ & $(0.54)$ & $(0.50)$ \\
\hline \multirow{2}{*}{ Export-price growth gr-4 $_{t}$} & -0.32 & $-0.82^{*}$ & $-1.33^{* * *}$ \\
\hline & $(0.37)$ & $(0.40)$ & $(0.33)$ \\
\hline \multirow{2}{*}{ Export-price growth gr-5 $_{t}$} & -0.31 & $-0.61^{*}$ & $-0.97^{* * *}$ \\
\hline & $(0.28)$ & $(0.32)$ & $(0.21)$ \\
\hline \multirow[t]{2}{*}{ Export-price growth $_{t-6}$} & -0.37 & -0.64 & $-0.60^{*}$ \\
\hline & $(0.34)$ & $(0.41)$ & $(0.34)$ \\
\hline \multirow[t]{2}{*}{ Export-price growth $_{t-7}$} & -0.16 & -0.29 & -0.34 \\
\hline & $(0.34)$ & $(0.39)$ & $(0.39)$ \\
\hline \multirow[t]{2}{*}{ Export-price growth $_{t-8}$} & -0.26 & -0.50 & -0.39 \\
\hline & $(0.34)$ & $(0.39)$ & $(0.33)$ \\
\hline \multirow[t]{2}{*}{ Export-price growth $_{t-9}$} & -0.01 & -0.45 & -0.42 \\
\hline & $(0.32)$ & $(0.36)$ & $(0.30)$ \\
\hline \multirow[t]{2}{*}{ Export-price growth ${ }_{t-10}$} & -0.33 & $-0.72^{* *}$ & $-0.79 * *$ \\
\hline & $(0.28)$ & $(0.31)$ & $(0.35)$ \\
\hline \multirow[t]{2}{*}{ Export-price growth g $_{t-11}$} & 0.02 & -0.37 & $-0.49^{*}$ \\
\hline & $(0.26)$ & $(0.30)$ & $(0.26)$ \\
\hline \multirow{2}{*}{ Export-price growth $_{t-12}$} & -0.18 & -0.41 & -0.60 \\
\hline & $(0.23)$ & $(0.29)$ & $(0.41)$ \\
\hline Year fixed effects & $\mathrm{X}$ & $\mathrm{X}$ & $\mathrm{X}$ \\
\hline \multirow[t]{2}{*}{ Constant } & $87.75^{* * *}$ & $89.42^{* * *}$ & $113.07^{* * *}$ \\
\hline & $(27.59)$ & $(26.70)$ & $(3.08)$ \\
\hline Observations & 8,732 & 8,732 & 5,870 \\
\hline Number of countries & 21 & 21 & 21 \\
\hline Adjusted R-squared & 0.26 & 0.27 & 0.23 \\
\hline
\end{tabular}

Table 8: Regression of the level of currency risk (measured in basis points) on the monthly growth rate of the principal-export price. Columns 2 and 3 allow the $\beta$ coefficient to be different if country is part of the periphery or the core (core coefficients not reported). Column 3 uses only observations for countries that are on the Gold Standard at $t$. ${ }^{* * *} \mathrm{p}<0.01,{ }^{* *} \mathrm{p}<0.05,{ }^{*} \mathrm{p}<0.1$. Robust standard errors in parentheses clustered at the country level. 


\begin{tabular}{|c|c|c|}
\hline & $(1)$ & $(2)$ \\
\hline & Core vs Periphery & Core vs Periphery on Gold \\
\hline \multirow[t]{2}{*}{ Export-price growth $_{t}$} & -0.41 & -0.44 \\
\hline & $(0.29)$ & $(0.37)$ \\
\hline \multirow[t]{2}{*}{ Export-price growth $_{t-1}$} & -0.39 & -0.71 \\
\hline & $(0.45)$ & $(0.55)$ \\
\hline \multirow[t]{2}{*}{ Export-price growth $_{t-2}$} & -0.56 & $-0.97^{*}$ \\
\hline & $(0.51)$ & $(0.54)$ \\
\hline \multirow[t]{2}{*}{ Export-price growth $_{t-3}$} & -0.67 & $-1.13^{* *}$ \\
\hline & $(0.48)$ & $(0.49)$ \\
\hline \multirow{2}{*}{ Export-price growth $_{t-4}$} & $-0.70^{*}$ & $-1.12^{* * *}$ \\
\hline & $(0.35)$ & $(0.34)$ \\
\hline \multirow{2}{*}{ Export-price growth $_{t-5}$} & $-0.52^{* *}$ & $-0.85^{* * *}$ \\
\hline & $(0.24)$ & $(0.16)$ \\
\hline \multirow[t]{2}{*}{ Export-price growth $_{t-6}$} & $-0.60^{* *}$ & $-0.54^{* *}$ \\
\hline & $(0.28)$ & $(0.20)$ \\
\hline \multirow[t]{2}{*}{ Export-price growth $_{t+1}$} & $-0.52^{*}$ & $-0.57^{*}$ \\
\hline & $(0.27)$ & $(0.28)$ \\
\hline \multirow[t]{2}{*}{ Export-price growth $_{t+2}$} & $-0.82^{* * *}$ & $-0.80 * * *$ \\
\hline & $(0.23)$ & $(0.28)$ \\
\hline \multirow[t]{2}{*}{ Export-price growth $_{t+3}$} & -0.36 & -0.32 \\
\hline & $(0.28)$ & $(0.28)$ \\
\hline \multirow[t]{2}{*}{ Export-price growth $_{t+4}$} & 0.21 & 0.49 \\
\hline & $(0.26)$ & $(0.35)$ \\
\hline \multirow{2}{*}{ Export-price growth $_{t+5}$} & 0.32 & 0.42 \\
\hline & $(0.29)$ & $(0.28)$ \\
\hline \multirow{2}{*}{ Export-price growth $_{t+6}$} & 0.25 & 0.24 \\
\hline & $(0.29)$ & $(0.23)$ \\
\hline Year fixed effects & $\mathrm{X}$ & $\mathrm{X}$ \\
\hline \multirow[t]{2}{*}{ Constant } & $89.48 * * *$ & $495.08^{* * *}$ \\
\hline & $(27.52)$ & $(7.57)$ \\
\hline Observations & 8,692 & 5,792 \\
\hline Number of countries & 21 & 21 \\
\hline Adjusted R-squared & 0.26 & 0.23 \\
\hline
\end{tabular}

Table 9: Regression of the level of currency risk (measured in basis points) on the monthly growth rate of the principal-export price. Columns 1 and 2 allow the $\beta$ coefficient to be different if country is part of the periphery or the core (core not reported). Column 2 uses only observations for countries that are on the Gold Standard at $t .{ }^{* * *} \mathrm{p}<0.01,{ }^{* *} \mathrm{p}<0.05,{ }^{*} \mathrm{p}<0.1$. Robust standard errors in parentheses clustered at the country level. 
are exogenous, these variables should not affect our coefficient of interest. We include monthly dummies that capture conflict (civil and foreign wars), whether a country has a central bank or a stock market, or whether it is experiencing default. As Table 15 in appendix $\mathrm{C}$ shows, the coefficient of export prices is relatively unchanged..$^{41}$

Finally, we include data on the trade balance and on the government bond spread over consols from Ferguson and Schularick (2006). It may be important to control for the former as negative shocks to export prices may lead to a deterioration of the trade balance. Under a formal commitment to gold, this may put pressure on the gold reserves and make leaving a peg more likely. Controlling for the spread of government bonds over consols may also be important since it allows us to explicitly test whether our measure for currency risk is capturing an effect independent of country or political risk. Given that these data vary at the yearly level, we augment our annual data specification reported in Table 4. Table 10 shows that the relationship between trade balance and currency risk is negative, but the coefficient for the growth rate in the price of exports is not sensitive to the inclusion of these controls, and even more precisely estimated than before. The coefficient for the spread of government bonds is not significantly different from zero in all specifications, suggesting that currency risk is not explained by sovereign-bond spreads. In column (5), we also control for reserves as a share of GDP using data from Accominotti et al. (2011). Unsurprisingly, reserves are an important determinant of currency-risk spreads. However, our coefficient of interest is again unchanged.

In appendix $\mathrm{C}$, we further show that our results are also robust to using desea-

\footnotetext{
${ }^{41}$ See Mitchener and Weidenmier (2015) for details and sources for these variables.
} 


\begin{tabular}{lccccc}
\hline \hline & $(1)$ & $(2)$ & $(3)$ & $(4)$ & $(5)$ \\
\hline & & & & & \\
Export-price growth & $-0.88^{* *}$ & $-0.89^{* *}$ & $-1.81^{* * *}$ & $-0.78^{* *}$ & $-0.75^{*}$ \\
& $(0.31)$ & $(0.35)$ & $(0.51)$ & $(0.35)$ & $(0.39)$ \\
Export-price growth x Core & $1.62^{*}$ & $2.08^{* *}$ & $1.80^{* * *}$ & $1.95^{* *}$ & $1.16^{*}$ \\
& $(0.80)$ & $(0.73)$ & $(0.52)$ & $(0.71)$ & $(0.59)$ \\
Trade balance \% of exports & -0.26 & & -0.41 & -0.50 & \\
& $(0.25)$ & & $(0.38)$ & $(0.29)$ & \\
Sovereign bond spread & & 0.00 & 0.19 & 0.01 & \\
Reserves \% of GDP & & $(0.08)$ & $(0.16)$ & $(0.09)$ & $-12.90^{* * *}$ \\
& & & & & $(3.34)$ \\
Year fixed effects & $\mathrm{X}$ & $\mathrm{X}$ & & $\mathrm{X}$ & $\mathrm{X}$ \\
Constant & $266.19 * * *$ & $227.71^{* * *}$ & $216.89^{* * *}$ & $223.74^{* * *}$ & $213.41^{* * *}$ \\
& $(24.46)$ & $(29.12)$ & $(34.22)$ & $(29.63)$ & $(19.14)$ \\
Observations & 499 & 417 & 417 & 417 & 402 \\
Adjusted R-squared & 0.45 & 0.45 & 0.07 & 0.46 & 0.61 \\
Number of countries & 16 & 16 & 16 & 16 & 13 \\
\hline \hline
\end{tabular}

Table 10: Regression of the level of currency risk on the annual growth rate of the principal-export price. The dummy variable Core takes on a value of 1 for the core countries identified in Table 2, zero otherwise. $\mathrm{x}$ represents an interaction. *** $\mathrm{p}<0.01,{ }^{* *} \mathrm{p}<0.05,{ }^{*} \mathrm{p}<0.1$. Robust standard errors in parentheses clustered at the country level. 
sonalized price series, removing near monopolists and famous re-exporters, augmenting the number of exports, adding principal imports for each country, and allowing estimated coefficients on export prices to differ across manufactures and commodity exporters.

\section{Conclusion}

We show theoretically and empirically that export-price shocks affect the expectation of currency devaluation. Using a simple model of strategic exit from a hard peg, we show that export prices are negatively related to the risk of "pegxit" and currency devaluation. The intuition behind our main theoretical result is that negative export-price shocks decrease government revenues, making it more likely that the government devalues domestic currency in order to decrease real debt-service payments, and ease fiscal pressures.

We test for the existence of this mechanism during the classical gold standard era, a period when hard pegs were the very foundation of the international monetary system. Under the identifying assumption that world prices are exogenous for price-taking economies, we find a negative causal relationship between the price of exports and currency risk, that is consistent with our theoretical results. This negatively-signed relationship is driven by countries on the periphery, and the effects are stronger when countries adhered to the gold standard.

Our model suggests several interesting extensions that could be pursued in future work. On the production side, we assumed long-run flexible prices and that devaluation decreases tax revenues from economic activity related to trade. Although these two assumptions are consistent with the classical gold standard 
era, it would be interesting to incorporate price-stickiness into the model and to study the mechanism through which currency devaluation can affect economic activity. Another interesting avenue for future research is to consider banks and firms balance-sheet currency mismatches, that can turn a currency devaluation into a banking crises.

Some of these extensions lend themselves to empirical work within the classical gold standard era. We have focused our empirical analysis on the principal export for each country. Although this was motivated by our theoretical approach as well as our desire to identify causal effects using an exogenous source of identification, including the full portfolio of exports and imports would allow us to assess the magnitude of the impact of trade shocks on currency risk. Finally, we have taken a partial equilibrium perspective on currency risk, where countries take international prices for their exports as given, and focused on shocks that propagate through trade. Besides participating in a global goods market for their exports, countries in the gold standard were linked also through imports as well as immigration and capital flows. In future work, we plan to study these relationships further.

\section{References}

Accominotti, Olivier, Marc Flandreau, and Riad Rezzik, "The spread of empire: Clio and the measurement of colonial borrowing costs," The Economic History Review, 2011, 64 (2), 385-407.

Aghion, Philippe, Philippe Bacchetta, and Abhijit Banerjee, "A corporate balance-sheet approach to currency crises," Journal of Economic Theory, 2004, 119 (1), 6-30.

Aguiar, Mark, Manuel Amador, Emmanuel Farhi, and Gita Gopinath, "Crisis and commitment: Inflation credibility and the vulnerability to sovereign debt crises," 2013.

Aizenman, Joshua and Reuven Glick, "Pegged Exchange Rate Regimes A Trap?," Journal of Money, Credit and Banking, 2008, 40 (4), 817-835. 
Angeletos, George-Marios, Christian Hellwig, and Alessandro Pavan, "Dynamic global games of regime change: Learning, multiplicity, and the timing of attacks," Econometrica, 2007, 75 (3), 711-756.

Bazzi, Samuel and Christopher Blattman, "Economic shocks and conflict: Evidence from commodity prices," American Economic Journal: Macroeconomics, 2014, 6 (4), 1-38.

Blattman, Christopher, Jason Hwang, and Jeffrey G Williamson, "Winners and losers in the commodity lottery: The impact of terms of trade growth and volatility in the Periphery 1870-1939," Journal of Development Economics, 2007, 82 (1), 156-179.

Bordo, Michael D and Christopher M Meissner, "The role of foreign currency debt in financial crises: 1880-1913 versus 1972-1997," Journal of Banking \& Finance, 2006, 30 (12), 3299-3329.

— and Finn E Kydland, "The gold standard as a rule: An essay in exploration," Explorations in Economic History, 1995, 32 (4), 423-464.

- and Hugh Rockoff, "The gold standard as a good housekeeping seal of approval," The Journal of Economic History, 1996, 56 (02), 389-428.

_ and Marc Flandreau, "Core, periphery, exchange rate regimes, and globalization," in "Globalization in historical perspective," University of Chicago Press, 2003, pp. 417-472.

British Board of Trade, Statistical Abstract for the Principal and Other Foreign Countries, London: Board of Trade, various years.

Broner, Fernando, "Discrete devaluations and multiple equilibria in a first generation model of currency crises," Journal of Monetary Economics, 2008, 55 (3), 592-605.

Burbidge, John B, Lonnie Magee, and A Leslie Robb, "Alternative transformations to handle extreme values of the dependent variable," Journal of the American Statistical Association, 1988, 83 (401), 123-127.

Burnside, Craig, Martin Eichenbaum, and Sergio Rebelo, "Prospective Deficits and the Asian Currency Crisis," Journal of Political Economy, 2001, 109 (6), 1155-1197.

_ , _ , and _ , "Government finance in the wake of currency crises," Journal of Monetary Economics, 2006, 53 (3), 401-440.

Calvo, Guillermo A, "Balance of payments crises in a cash-in-advance economy," Journal of Money, Credit and Banking, 1987, pp. 19-32.

_ , "Servicing the public debt: The role of expectations," The American Economic Review, 1988, pp. 647-661.

Carroll, Christopher D, Karen E Dynan, and Spencer D Krane, "Unemployment risk and precautionary wealth: Evidence from households' balance sheets," Review of Economics and Statistics, 2003, 85 (3), 586-604.

Caselli, Francesco and Andrea Tesei, "Resource Windfalls, Political Regimes, and Political Stability," Review of Economics and Statistics, July 2016, 98 (3), 573590. 
Chernyshoff, Natalia, David S Jacks, and Alan M Taylor, "Stuck on gold: Real exchange rate volatility and the rise and fall of the gold standard, 1875-1939," Journal of International Economics, 2009, 77 (2), 195-205.

Chirot, Daniel, The origins of backwardness in Eastern Europe: Economics and politics from the Middle Ages until the early twentieth century, Univ of California Press, 1991.

Christiano, Lawrence J and Terry J Fitzgerald, "The Band Pass Filter," International Economic Review, 2003, 44 (2), 435-465.

Collier, Simon and William F Sater, A History of Chile: 1808-1994, Cambridge University Press, 1996.

Corsetti, Giancarlo and Luca Dedola, "The Mystery of the Printing Press: Self-fulfilling debt crises and monetary sovereignty," Journal of European Economic Association, 2016, forthcoming.

_ , Paolo Pesenti, and Nouriel Roubini, "Paper tigers?: A model of the Asian crisis," European Economic Review, 1999, 43 (7), 1211-1236.

Edwards, Sebastian, Domingo F Cavallo, Arminio Fraga, and Jacob Frenkel, "Exchange rate regimes," in "Economic and financial crises in emerging market economies," University of Chicago Press, 2003, pp. 31-92.

Eichengreen, Barry, Globalizing capital: a history of the international monetary system, Princeton University Press, 1998.

_ , Jaime Reis, Jorge Braga de Macedo et al., Currency convertibility: the gold standard and beyond, Routledge, 2005.

Estevadeordal, Antoni, Brian Frantz, and Alan M Taylor, "The Rise and Fall of World Trade, 1870-1939," The Quarterly Journal of Economics, 2003, 118 (2), 359-407.

Ferguson, Niall and Moritz Schularick, "The empire effect: the determinants of country risk in the first age of globalization, 1880-1913," The Journal of Economic History, 2006, 66 (02), 283-312.

Findlay, Ronald and Kevin H O'Rourke, "Commodity market integration, 1500-2000," in "Globalization in historical perspective," University of Chicago Press, 2003, pp. 13-64.

Flandreau, Marc and Mathilde Maurel, "Monetary union, trade integration, and business cycles in 19th century Europe," Open Economies Review, 2005, 16 (2), 135-152.

_, Jacques Le Cacheux, and Frédéric Zumer, "Stability without a pact? Lessons from the European gold standard, 1880 - 1914," Economic Policy, 1998, 13 (26), 116-162.

Flood, Robert $\mathbf{P}$ and Peter $\mathbf{M}$ Garber, "Collapsing exchange-rate regimes: some linear examples," Journal of International Economics, 1984, 17 (1), 1-13.

Gali, Jordi and Tommaso Monacelli, "Monetary policy and exchange rate volatility in a small open economy," The Review of Economic Studies, 2005, 72 (3), 707-734. 
Gupta, Poonam, Deepak Mishra, and Ratna Sahay, "Behavior of output during currency crises," Journal of International Economics, 2007, 72 (2), 428-450.

Hanson, John R, Trade in transition: exports from the Third World, 1840-1900, Academic Press New York, 1980.

Hjerppe, Riitta, The Finnish economy 1860-1985: Growth and structural change, Vol. 13, Bank of Finland, 1989.

Husain, Aasim M, Ashoka Mody, and Kenneth S Rogoff, "Exchange rate regime durability and performance in developing versus advanced economies," Journal of Monetary Economics, 2005, 52 (1), 35-64.

Jacks, David S, "From boom to bust: A typology of real commodity prices in the long run," Technical Report, National Bureau of Economic Research 2013.

Jacobson, Morris Lazarev, Statistical Abstract of Foreign Countries: Part I-III. Statistics of Foreign Commerce. October, 1909, US Government Printing Office, 1909.

Johansson, Östen, "The gross domestic product of Sweden and its composition 1861-1955," 1967.

Kamin, Steven B, Devaluation, external balance, and macroeconomic performance: a look at the numbers, International Finance Section, Department of Economics, Princeton University, 1988.

Kaminsky, Graciela L and Carmen M Reinhart, "The twin crises: the causes of banking and balance-of-payments problems," American Economic Review, 1999, pp. 473-500.

Kaminsky, Graciela, Saul Lizondo, and Carmen M Reinhart, "Leading indicators of currency crises," Staff Papers, 1998, 45 (1), 1-48.

Kollmann, Robert, "Monetary policy rules in the open economy: effects on welfare and business cycles," Journal of Monetary Economics, 2002, 49 (5), 989-1015.

Krugman, Paul, "A model of balance-of-payments crises," Journal of Money, Credit and Banking, 1979, pp. 311-325.

_ , "Balance sheets, the transfer problem, and financial crises," in "International finance and financial crises," Springer, 1999, pp. 31-55.

Leland, Hayne E, "Corporate debt value, bond covenants, and optimal capital structure," The Journal of Finance, 1994, 49 (4), 1213-1252.

López-Córdova, J Ernesto and Christopher M Meissner, "Exchange-rate regimes and international trade: Evidence from the classical gold standard era," American Economic Review, 2003, pp. 344-353.

Mitchell, Brian R, "International Historical Statistics: Africa and Asia," 1982.

_ , European Historical Statistics, 1750-2005, Macmillan London, 2007. 
_ , International Historical Statistics 1750-2005: Americas, Macmillan London, 2007.

Mitchener, Kris James and Hans-Joachim Voth, "Trading Silver for Gold: Nineteenthcentury Asian Exports and the Political Economy of Currency Unions," 2011.

_ and Marc D Weidenmier, "Are hard pegs ever credible in emerging markets? Evidence from the Classical Gold Standard," The Journal of Economic History, 2015.

_ and Marc Weidenmier, "Trade and Empire," The Economic Journal, 2008, 118 (533), $1805-1834$.

- and Se Yan, "Globalization, trade, and wages: What does history tell us about China?," International Economic Review, 2014, 55 (1), 131-168.

_ , Masato Shizume, and Marc D Weidenmier, "Why did countries adopt the gold standard? Lessons from Japan," The Journal of Economic History, 2010, 70 (01), 27-56.

Na, Seunghoon, Stephanie Schmitt-Grohé, Martin Uribe, and Vivian Z Yue, "A model of the twin ds: Optimal default and devaluation," Technical Report, National Bureau of Economic Research 2014.

Neal, Larry D and Marc D Weidenmier, "Crises in the global economy from tulips to today," in "Globalization in historical perspective," University Of Chicago Press, 2003, pp. 473-514.

Obstfeld, Maurice, "Rational and Self-fulfilling Balance-of-Payments Crises," American Economic Review, 1986, 76 (1), 72-81.

_ and Alan M Taylor, "Sovereign risk, credibility and the gold standard: 1870-1913 versus 1925-31," The Economic Journal, 2003, 113 (487), 241-275.

_ and Kenneth Rogoff, "The Mirage of Fixed Exchange Rates," The Journal of Economic Perspectives, 1995, pp. 73-96.

_ , Jay C Shambaugh, and Alan M Taylor, "The trilemma in history: tradeoffs among exchange rates, monetary policies, and capital mobility," Review of Economics and Statistics, $2005,87(3), 423-438$.

O'Rourke, Kevin and Jeffrey G Williamson, "Late nineteenth-century Anglo-American factor-price convergence: were Heckscher and Ohlin right?," The Journal of Economic History, 1994, 54 (04), 892-916.

Rebelo, Sergio and Carlos A Végh, "When is it optimal to abandon a fixed exchange rate?," The Review of Economic Studies, 2008, 75 (3), 929-955.

Reinhart, Carmen $\mathbf{M}$ and Kenneth Rogoff, This time is different: eight centuries of financial folly, princeton university press, 2009.

_, Vincent Reinhart, and Christoph Trebesch, "Global Cycles: Capital Flows, Commodities, and Sovereign Defaults, 1815-2015," The American Economic Review, 2016, 106 (5), 574-580. 
Rose, Andrew K, "” Exchange Rate Regimes in the Modern Era": Fixed, Floating, and Flaky," Journal of Economic Literature, 2011, pp. 652-672.

Schmitt-Grohé, Stephanie and Martın Uribe, "Downward nominal wage rigidity, currency pegs, and involuntary unemployment," Journal of Political Economy, October 2016, 124 (5), $1466-1514$.

Schmukler, Sergio L and Luis Servén, "Pricing currency risk under currency boards," Journal of Development Economics, 2002, 69 (2), 367-391.

Shreve, Steven E, Stochastic calculus for finance II: Continuous-time models, Vol. 11, Springer Science \& Business Media, 2004.

Silverman, AG, "Monthly Index Numbers of British Export and Import Prices, 1880-1913," The Review of Economic Statistics, 1930, pp. 139-148.

Williamson, Jeffrey G, "Globalization and the Great Divergence: terms of trade booms, volatility and the poor periphery, 1782-1913," European Review of Economic History, 2008, $12(3), 355-391$.

_ , "Trade and Poverty: When the Third World Fell Behind," MIT Press Books, 2013, 1.

Wooldridge, Jeffrey M, "Fixed-effects and related estimators for correlated random-coefficient and treatment-effect panel data models," Review of Economics and Statistics, 2005, 87 (2), $385-390$. 


\section{Appendix A Periods of gold standard adherence}

\begin{tabular}{ll}
\hline Country & Gold dates \\
\hline Argentina & $1870 \mathrm{~m} 1-1876 \mathrm{~m} 6^{*}, 1883 \mathrm{~m} 7-1885 \mathrm{~m} 1$ and $1899 \mathrm{~m} 11-1914 \mathrm{~m} 6$ \\
Austria-Hungary & $1892 \mathrm{~m} 8-1914 \mathrm{~m} 6$ \\
Belgium & $1878 \mathrm{~m} 11-1914 \mathrm{~m} 6$ \\
Bulgaria & $1902 \mathrm{~m} 11-1912 \mathrm{~m} 10$ \\
Chile & $1895 \mathrm{~m} 6-1898 \mathrm{~m} 7$ \\
Denmark & $1873 \mathrm{~m} 5-1914 \mathrm{~m} 6$ \\
Finland & $1877 \mathrm{~m} 12-1914 \mathrm{~m} 6$ \\
France & $1878 \mathrm{~m} 11-1914 \mathrm{~m} 6$ \\
Germany & $1871 \mathrm{~m} 10-1914 \mathrm{~m} 6$ \\
Greece & $1885 \mathrm{~m} 1-1885 \mathrm{~m} 8^{*}, 1910 \mathrm{~m} 3-1914 \mathrm{~m} 6$ \\
India & $1898 \mathrm{~m} 1-1914 \mathrm{~m} 6$ \\
Italy & $1883 \mathrm{~m} 2-1894 \mathrm{~m} 12$ \\
Japan & $1897 \mathrm{~m} 9-1914 \mathrm{~m} 6$ \\
Mexico & $1905 \mathrm{~m} 4-1913 \mathrm{~m} 12$ \\
Netherlands & $1875 \mathrm{~m} 6-1914 \mathrm{~m} 6$ \\
Norway & $1873 \mathrm{~m} 5-1914 \mathrm{~m} 6$ \\
Romania & $1890 \mathrm{~m} 4-1914 \mathrm{~m} 6$ \\
Russia & $1897 \mathrm{~m} 1-1914 \mathrm{~m} 6$ \\
Sweden & $1873 \mathrm{~m} 5-1914 \mathrm{~m} 6$ \\
Switzerland & $1878 \mathrm{~m} 12-1914 \mathrm{~m} 6$ \\
USA & $1879 \mathrm{~m} 1-1914 \mathrm{~m} 6$ \\
\hline
\end{tabular}

Table 11: De jure gold adherence dates are fromMitchener and Weidenmier (2015), except ${ }^{*}$ from Eichengreen et al. (2005). 


\section{Appendix B Prices and principal exports}

In this Appendix, we describe the sources and calculations used to create our series for principal exports and export prices.

\section{B.1 Price series notes}

We collected a number of monthly price series for different products from the Economist's Monthly Trade Supplement and Weekly Price Current. We select the price series that maximizes data coverage and consistency throughout our sample (1870-1913). This is important as some price series change units or definitions. ${ }^{42}$ We also use a price index for British textile exports from Silverman (1930) that is available between 1880 - 1913 to proxy for cotton and wool manufactures. ${ }^{43}$ We create price indices for each relevant product-price series that take on the value of 100 for the average of the 1913 price. We select 1913 as our base year because the initial date for which we have data varies across goods whereas this date is available for all goods. The list below provides details on the particular price series taken from the Economist (as displayed therein):

Beef: Inferior.

Butter: Prices series for Dutch (including Friesland) and Danish butter.

Coal: Best Wallsend London.

\footnotetext{
${ }^{42}$ We have confirmed that our empirical results hold in sub-samples that exclude any product definitional changes.

${ }^{43}$ Since the main source of monthly variation in cotton and wool textiles would come from changes in the prices of the commodity input, it is not surprising that our empirical results are robust to proxying the price of cotton manufactures with a cotton price index that is available between 1870 and 1914 (the monthly correlation between the cotton index and the monthly index for textile products price index is 0.76 ), and the price of wool manufactures with a wool price index that is available between 1870 and 1914 (the monthly correlation between the price of wool and the price of textile products is 0.78 .).
} 
Coffee: Between 1870-1881, Jamaica Fine Ord. to Fine. Between 1881-1913, Ceylon, Plantation. Low mid changed to Santos Good Average in 1908.

Copper: Between 1870-1881, Copper: Tough Cake. Between 1881-1913, Chili

Bars changed to G.M.B in 1899, Standard in 1912.

Cotton: Between 1870-1881, Mule No 40, Fair, 2nd quality, Manchester Markets.

Between 1881-1913, Yarn-40 Mule Twist.

Flax: Between 1870-1881, Friesland. Between 1881-1913, Petersburg 12-head, changed to Riga, ZK in 1895.

Flour: Town Made 2ends, changed to Town House holds in 1910.

Hemp: Between 1870-1881, Manilla. Between 1881-1913, St Petersburg Clean

Raw.

Iron: British mid.

Lead: English Pig.

Nitrate: Saltpetre English refined.

Oats: Gazette Averages (English Grain) - Oats.

Olive Oil: Between 1870-1881, Olive, Gallipoli. After 1881, Olive Levant/ After 1885 changed to Spanish, 1911 to Palm. Lagos.

Rice: Rangoon.

Silver: London market price.

Silk: Between 1870-1881, Raw Cossimbuzar. Between 1881-1913, Cossimbuzar.

Sugar: Between 1870-1881, Bengal Good Yellow and White. Between 1881-1902, West India Refining. Between 1902-1913, West India Syrups.

Timber: Prices series for Swedish, Norwegian and Finnish timber from the

Weekly Price Current.

Tea: Tea Congou - 1905 changed to Fr. Gd.. 
Textiles: Average export prices from foreign trade statistics for cotton cloth, woolen and worsted yarn and goods, and for linen and jute piece goods.

Wheat: Between 1870-1881, Wheat Gazette Average. Between 1881-1913, Gazette Averages (English Grain).

Wood: Price series for Norwegian, Swedish and Finnish timber.

Wool: Sydney Unwashed/Changed to NS.Wles Greasy Average in 1891.

Wheat: Gazette Averages (English Grain) - Wheat.

\section{B.2 Principal exports}

For most countries in our sample, we primarily rely on detailed trade data published in the British Board of Trade (various years) Statistical Abstract, henceforth SA, to identify principal exports. We supplement and cross-check our estimates with information found in Mitchell (2007b), Mitchell (1982), Hanson (1980), as well as country-specific sources. Appendix Table 1 shows each economy's largest export for 1870, 1880, 1890, 1900 and 1910 (when available). The list below summarizes our findings: ${ }^{44}$

Argentina: Wool. Mitchell (2007b) reports that the average value of wool exports for Argentina between 1870 and 1914 was 40.2 million gold pesos, compared to 35.7 million gold pesos for wheat and 22.4 million gold pesos for hides and skins. According to SA, wool accounted between 49.9\% of Argentina's exports (1889) and $19.9 \%$ in 1904 .

Austria-Hungary: Wood. According to SA, wood is the largest export for Austria-Hungary in our sample (largest export for 14 years). Sugar follows

\footnotetext{
${ }^{44}$ Imports and source data available on request.
} 
closely (11 years). Hanson (1980) reports that for 1900 the largest export for Austria was raw sugar (37.9 million U.S. dollars), followed by cotton manufactures (4.6 million U.S. dollars). Given that we do not have price data on Austrian-Hungarian wood, we use the price of Swedish wood as a proxy.

Belgium: Flour. According to SA, flour is the largest export for Belgium in our sample (largest export for 11 years), followed by coal and iron.

Bulgaria: Wheat. According to SA, wheat is consistently the largest export for Bulgaria. Chirot (1991) reports that wheat sales represented 70\% of Bulgaria's export totals around 1900 .

Chile: Nitrate. Mitchell (2007b) reports that the average value of copper exports between 1870 and 1914 was 29.6 million gold pesos of 18 pence, which is smaller than the value of nitrate exports for the same period (125.4 million gold pesos of 18 pence).

Denmark: Butter. According to SA, flour and butter are the most representative exports for Denmark. Flour accounts for a larger share of exports early in our sample period, whereas butter dominates after 1890. We use the monthly price of Dutch butter to proxy for Danish butter, for which we only have data from 1894 onwards. The correlation coefficient between Danish and Dutch butter following 1894 is 0.87 .

Finland: Wood. Hjerppe (1989) report that timber and wood products accounted for $46 \%$ of Finnish exports between 1869-1913.

France: Textile manufactures. According to SA, wool, silk and cotton manufactures represent the largest exports for France, followed by wine and hides. Hanson (1980) reports that for 1900 the largest export for France are silk 
manufactures (61.5 million U.S. dollars), followed by cotton manufactures (34.9 million U.S. dollars). Given that we do not have monthly data for France's textile manufactures we proxy the price of France's largest export with an index for textile products from Silverman (1930).

Germany: Iron products. According to SA, iron products are the largest export for Germany for 13 years, followed by wool manufactures and flour. Hanson (1980) reports that for 1900 the largest export for Germany are cotton manufactures (67.1 million U.S. dollars), followed by raw sugar (51.5 million U.S. dollars).

Greece: Iron. According to SA, the main export are dried fruits, for which we do not have monthly price data, followed by ore (as high as 30\% of exports in 1895). Blattman et al. (2007) reports that fruits \& nuts account for $59 \%$ of Greece's exports between 1898 and 1902. The second largest export is lead, accounting for $14.1 \%$.

India: Cotton. Mitchell (1982) reports that the average value of cotton exports between 1870 and 1913 was 167.3 million rupees. Rice accounts for the second largest export, averaging 128.2 million rupees, followed by opium, jute, cotton manufactures, tea and jute manufactures. Blattman et al. (2007) reports that rice accounts for $21.1 \%$ of Indias's exports between 1898 and 1902. Other important exports include cotton $(16.9 \%)$, cotton manufactures $(13.8 \%)$, jute $(13.7 \%)$, tea $(12.2 \%)$, opium $(11.7 \%)$ and jute manufactures $(10.6 \%)$.

Italy: Silk. SA reports that silk, raw and thrown waste cocoons account for the largest share of Italy's exports, followed by silk manufactures. Hanson (1980) reports that for 1900 the largest export for Italy are silk manufactures (86.6 
million U.S. dollars), followed by cotton manufactures (11.8 million U.S. dollars). Japan: Silk. Mitchell (1982) reports that the average value of raw silk exports between 1870 and 1913 was 46.15 million yen, followed by cotton yarn \& fabrics $(25.9 \%)$ and silk fabrics (19\%). We confirmed this using SA.

Mexico: Silver. Mitchell (2007b) reports that the average value of silver exports between 1870 and 1913 was 52.5 million pesos, much larger than the second largest export, coffee (6.7 million pesos).

Netherlands: Flour. SA reports that drugs are the largest export for the Netherlands, followed by flour and wheat. Hanson (1980) reports that for 1900 the largest export for Netherlands are cotton manufactures (16.2 million U.S. dollars), followed by Dyes and Dyestuffs (9.1 million dollars). Given that the Netherlands monopolizes the market for Peruvian bark, we select flour as the main export, for which we have monthly prices.

Norway: Wood. SA reports that wood and fish are the largest exports for Norway. Blattman et al. (2007) reports that wood and products accounted for 44.2\% of Norway's exports between 1898 and 1902. Fish accounts for the largest percentage of exports during this period (50.1\%), but we do not have monthly data for Norwegian fish and opt to use Norwegian timber instead.

Romania: Wheat. SA reports that wheat is the largest export for Romania, followed by maize, barley and flax. Chirot (1991) reports that wheat sales represented $80 \%$ of Romania's export totals around 1900.

Russia: Wheat. SA reports that wheat is the largest export for Russia followed by flax and barley. Blattman et al. (2007) reports that grain accounted for $63.0 \%$ of Russia's exports between 1898 and 1902, 65.0\% between 1878 and 1882 . 
Sweden: Wood. SA reports that wood is the largest export for Sweden, followed by iron products, oats and butter. Johansson (1967) reports that, between 1891 and 1895, wood products accounted for $28 \%$ of Sweden's exports.

Switzerland: Textile manufactures. SA reports that silk and cotton manufactures represent the largest exports for Switzerland. Hanson (1980) reports that in 1900 the largest export for Switzerland are silk manufactures (40.7 million U.S. dollars), closely followed by cotton manufactures (32.9 million U.S. dollars). United States of America: Cotton. SA reports that cotton is the largest export for the USA, followed by wheat and meat and sausages. Mitchell (2007b) reports that the average value of cotton exports between 1870 and 1913 was 250 million U.S. dollars, larger than the second largest export, wheat (averaging 108 million U.S. dollars). 


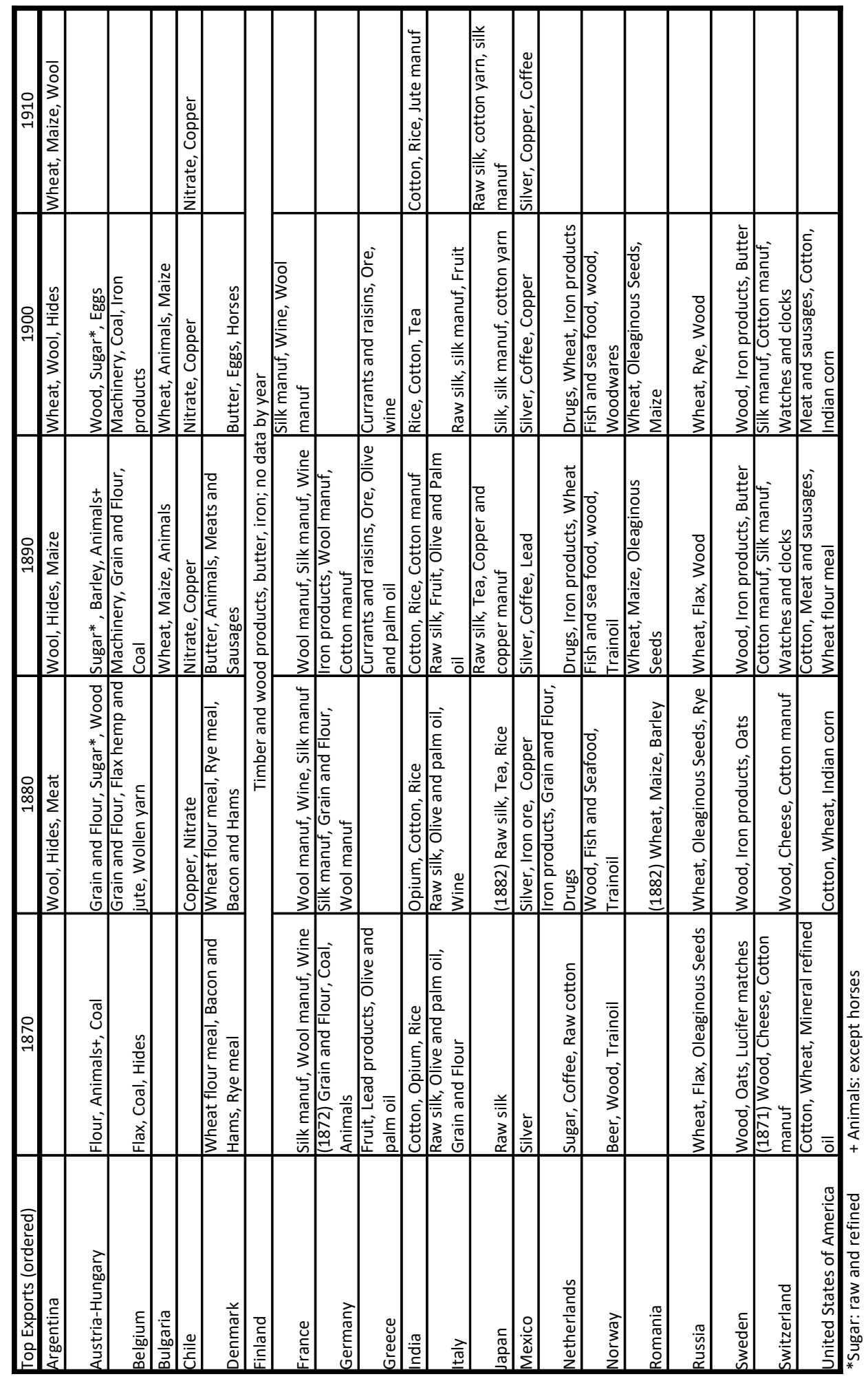

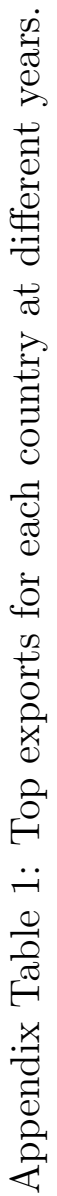




\section{Appendix C Additional empirical results}

In this Appendix, we show that our results are also robust to the following alternative specificaitons: using deseasonalized price series; removing near monopolists and famous re-exporters; augmenting the number of exports; adding principal imports for each country; and allowing estimated coefficients on export prices to differ across manufactures and commodity exporters.

Some of the monthly variation in commodity prices may reflect seasonality in supply and demand and thus be predictable from the currency traders' perspective. Supply seasonality is associated with the natural growth or extraction calendars, while demand seasonality comes from general economic activity. This seasonality in international supply and demand may affect the price of exports for our countries at the monthly frequency, but is not necessarily associated with the permanent shocks we considered in our theoretical model, and therefore may not be causing currency risk. As a consequence, using seasonally unadjusted data can potentially bias the $\beta$ coefficient estimated using the panel defined by equation (18). Table 12 reproduces the structural analysis from Table 4 but uses deseasonalized price data. It shows that results are virtually unchanged.

In Table 13, we investigate the robustness of the reduced-form results by studying more exogenous exports, but also a larger number of exports and imports. In Column (1), we replace some of the main exports in Table 2 by main exogenous exports. To be exact, we replace nitrate with copper for Chile and remove the Netherlands from our sample. We can see that the effect size for the periphery is 


\begin{tabular}{|c|c|c|c|c|c|c|}
\hline & $(1)$ & $(2)$ & $(3)$ & $(4)$ & $(5)$ & $(6)$ \\
\hline Export price & $\begin{array}{c}-0.56^{* * *} \\
(0.15)\end{array}$ & $\begin{array}{l}-0.10 \\
(0.14)\end{array}$ & $\begin{array}{l}-0.24 \\
(0.15)\end{array}$ & $\begin{array}{l}-0.24 \\
(0.18)\end{array}$ & $\begin{array}{c}\text { On Gold } \\
-0.27^{*} \\
(0.15)\end{array}$ & $\begin{array}{c}\text { Not on Gold } \\
-0.29^{*} \\
(0.15)\end{array}$ \\
\hline Export price $\mathrm{x}$ Core & & & $\begin{array}{c}0.61^{* *} \\
(0.27)\end{array}$ & $\begin{array}{c}1.47^{* * *} \\
(0.24)\end{array}$ & $\begin{array}{l}0.70^{* *} \\
(0.29)\end{array}$ & $\begin{array}{c}1.31^{* * *} \\
(0.31)\end{array}$ \\
\hline Gold & & & & $\begin{array}{c}0.13 \\
(0.59)\end{array}$ & & \\
\hline Export price x Gold & & & & $\begin{array}{l}-0.00 \\
(0.14)\end{array}$ & & \\
\hline Core x Gold & & & & $\begin{array}{c}4.00^{* * *} \\
(1.23)\end{array}$ & & \\
\hline Export price x Core x Gold & & & & $\begin{array}{c}-0.87^{* * *} \\
(0.27)\end{array}$ & & \\
\hline Year fixed effects & & $\mathrm{X}$ & $\mathrm{X}$ & $\mathrm{X}$ & $\mathrm{X}$ & $\mathrm{X}$ \\
\hline Constant & $\begin{array}{c}3.56^{* * *} \\
(0.68)\end{array}$ & $\begin{array}{c}0.87 \\
(0.80)\end{array}$ & $\begin{array}{c}0.72 \\
(0.80)\end{array}$ & $\begin{array}{l}-0.43 \\
(1.00)\end{array}$ & $\begin{array}{c}0.56 \\
(0.71)\end{array}$ & $\begin{array}{c}2.78^{* * *} \\
(0.68)\end{array}$ \\
\hline Observations & 8,901 & 8,901 & 8,901 & 8,901 & 5,926 & 2,975 \\
\hline Adjusted R-squared & 0.03 & 0.21 & 0.22 & 0.22 & 0.22 & 0.25 \\
\hline Number of countries & 21 & 21 & 21 & 21 & 21 & 16 \\
\hline
\end{tabular}

Table 12: Regression of $H\left(C R S_{c, t}\right)$ on the log of principal export price (deseasonalized), $H\left(C R S_{c, t}\right)$ defined in equation (19). Core takes on a value of 1 for the core countries, zero otherwise. Gold takes on a value of 1 if the country has a formal gold commitment in place, zero otherwise. $\mathrm{x}$ represents interaction. $\mathrm{p}<0.01,{ }^{* *} \mathrm{p}<0.05,{ }^{*} \mathrm{p}<0.1$. Robust standard errors in parentheses clustered at the country level. 
robust to using more exogenous exports and to removing a notable re-exporter. ${ }^{45}$ In Column (2), we add the second largest export to the principal export identified in Table 2, while in Column (3) we add the main import together with the principal export. Finally, in Column (4) we include the 3 main exports and the 3 main imports. The coefficient on the primary export is negative throughout. In general, only export-price growth coefficients are significantly different from zero for the periphery, which is consistent with our focus on principal exports as a crucial determinant of income and economic activity.

In Table 14, we allow the estimated coefficient on export-price growth to differ between manufactures and commodity exporters. Belgium, Denmark, France, Germany, Netherlands and Switzerland are classified as countries for which the principal export is a manufacture while the remaining countries are commodity exporters. The first line collects the results for commodity exporters. We can see that the coefficient is negative throughout, and that the effect of export prices is stronger while on gold. This negative coefficient is further reduced if we remove the United States from the set of commodity exporters, or consider only periphery countries. Finally, Table 15 reports that our results are robust to including monthly dummies capturing institutional variables and country-specific events as described in Section 4.

\footnotetext{
${ }^{45}$ We have also ran specifications removing other potential exporters with market power, for example, the USA in the market for cotton, or Russia in the market for wheat, and found similar results.
} 
Exogenous export-price growth

$-0.50^{* *}$

(0.19)

Exogenous export-price growth x Core

$1.22^{* * *}$

(0.35)

Export 1 price growth x Core

Import 1 price growth

Import 1 price growth $\mathrm{x}$ Core

Export 2 price growth

Export 2 price growth $\mathrm{x}$ Core

Import 2 price growth $\mathrm{x}$ Core

Export 3 price growth

Export 3 price growth $\mathrm{x}$ Core

Import 3 price growth
Export 1 price growth

Import 2 price growth

$$
\begin{gathered}
-0.39 \\
(0.24) \\
0.82^{*} \\
(0.40) \\
\\
\\
\\
-0.24^{*} \\
(0.13) \\
0.73^{* *} \\
(0.29)
\end{gathered}
$$

Import 3 price growth $\mathrm{x}$ Core

Year fixed effects

Constant

$\begin{array}{cc}\mathrm{X} & \mathrm{X} \\ 98.11^{* * *} & 250.15^{* * *} \\ (27.10) & (40.36) \\ 8,374 & 8,359 \\ 0.27 & 0.27 \\ 20 & 21\end{array}$

Observations

Adjusted R-squared

Number of countries

-0.41
$(0.26)$
$0.92^{* *}$
$(0.40)$
-0.09
$(0.12)$
$0.52^{* * *}$
$(0.16)$

$-0.44^{*}$

$(0.25)$

$0.79^{*}$

$(0.39)$

0.03

$(0.12)$

0.23

(0.18)

$-0.16$

(0.10)

0.44

$(0.27)$

-0.30 *

(0.16)

$0.58^{* * *}$

(0.20)

$-0.75^{* *}$

(0.29)

$1.15^{* *}$

(0.44)

0.01

(0.13)

0.27

$(0.33)$

$-0.10$

$(0.09)$

0.21

(0.37)

$-0.20$

$(0.17)$

$0.39^{*}$

$(0.22)$

$-0.09$

(0.12)

0.30

$(0.36)$

$-0.16$

$(0.24)$

0.36

$(0.26)$

$$
\mathrm{X}
$$

$245.53^{* * *}$

$(33.95)$
8,447
0.26
(33.95)

$\mathrm{X}$
$302.73^{* * *}$
$(8.20)$
7,877
0.27

Table 13: Regression of the level of currency risk (measured in basis points) on the yearly growth rate of the principal exports and imports price, where 1 stands for principal, 2 for second principal, and 3 for third principal. Core takes on a value of 1 for the core countries, zero otherwise. Gold takes on a value of 1 if the country has a formal gold commitment in place, zero otherwise. $\mathrm{x}$ represents interaction. *** $\mathrm{p}<0.01,{ }^{* *} \mathrm{p}<0.05,{ }^{*} \mathrm{p}<0.1$. Robust8standard errors in parentheses clustered at the country level. 


\begin{tabular}{lccc}
\hline \hline & $(1)$ & $(2)$ & $(3)$ \\
\hline & & & \\
Export-price growth & $-0.73^{*}$ & -0.30 & -0.15 \\
& $(0.37)$ & $(0.27)$ & $(0.40)$ \\
Export-price growth x Manufacture & 0.34 & 0.67 & 0.01 \\
& $(0.43)$ & $(0.41)$ & $(0.43)$ \\
Gold & & -0.62 \\
& & & $(21.24)$ \\
Export-price growth x Gold & & -0.27 \\
& & & $(0.49)$ \\
Manufacture x Gold & & -8.63 \\
& & & $(34.90)$ \\
Export-price growth x Gold x Manufacture & & 0.79 \\
& & $\mathrm{X}$ & $(0.62)$ \\
Year fixed effects & & $\mathrm{X}$ \\
Constant & & & $239.17^{* * *}$ \\
& & & $(23.52)$ \\
Observations & & & 8.748 \\
Adjusted R-squared & 8,748 & 8,748 & 0.26 \\
Number of countries & 0.00 & 0.26 & 21 \\
\hline \hline
\end{tabular}

Table 14: Regression of the level of currency risk (measured in basis points) on the yearly growth rate of the principal-export monthly price. Manufacture takes on a value of 1 if principal export is a manufactured good, zero if it is a commodity. Gold takes on a value of 1 if the country has a formal gold commitment in place, zero otherwise. Core takes on a value of 1 for the core countries, zero otherwise. $\mathrm{x}$ represents interaction. ${ }^{* * *} \mathrm{p}<0.01,{ }^{* *} \mathrm{p}<0.05,{ }^{*} \mathrm{p}<0.1$. Robust standard errors in parentheses clustered at the country level. 


\begin{tabular}{|c|c|c|c|c|c|c|}
\hline & $(1)$ & $(2)$ & $(3)$ & $(4)$ & $(5)$ & $(6)$ \\
\hline Export-price growth & $\begin{array}{c}-0.44^{*} \\
(0.24)\end{array}$ & $\begin{array}{c}-0.44^{*} \\
(0.25)\end{array}$ & $\begin{array}{c}-0.44^{*} \\
(0.24)\end{array}$ & $\begin{array}{l}-0.42 \\
(0.25)\end{array}$ & $\begin{array}{c}-0.72^{*} \\
(0.38)\end{array}$ & $\begin{array}{l}-0.42 \\
(0.25)\end{array}$ \\
\hline Export-price growth x Core & $\begin{array}{l}1.03^{* *} \\
(0.39)\end{array}$ & $\begin{array}{l}1.03^{* *} \\
(0.39)\end{array}$ & $\begin{array}{l}1.03^{* *} \\
(0.39)\end{array}$ & $\begin{array}{c}0.99^{* *} \\
(0.39)\end{array}$ & $\begin{array}{c}0.45 \\
(0.44)\end{array}$ & $\begin{array}{c}0.99^{* *} \\
(0.39)\end{array}$ \\
\hline Intra-state war & & $\begin{array}{c}4.76 \\
(41.51)\end{array}$ & & & $\begin{array}{c}-8.89 \\
(43.31)\end{array}$ & $\begin{array}{c}3.41 \\
(40.35)\end{array}$ \\
\hline Inter-state war & & $\begin{array}{l}-12.99 \\
(31.97)\end{array}$ & & & $\begin{array}{c}-9.21 \\
(34.15)\end{array}$ & $\begin{array}{l}-13.88 \\
(32.29)\end{array}$ \\
\hline Central bank & & & $\begin{array}{c}0.05 \\
(18.81)\end{array}$ & & $\begin{array}{c}-35.67^{* *} \\
(16.86)\end{array}$ & $\begin{array}{c}0.06 \\
(18.89)\end{array}$ \\
\hline Stock market & & & $\begin{array}{c}9.34 \\
(18.89)\end{array}$ & & $\begin{array}{c}-9.16 \\
(25.57)\end{array}$ & $\begin{array}{c}8.66 \\
(19.33)\end{array}$ \\
\hline Default & & & & $\begin{array}{l}115.35 \\
(67.27)\end{array}$ & $\begin{array}{c}238.94^{* * *} \\
(60.55)\end{array}$ & $\begin{array}{c}115.88^{*} \\
(66.66)\end{array}$ \\
\hline Year fixed effects & $\mathrm{X}$ & $\mathrm{X}$ & $\mathrm{X}$ & $\mathrm{X}$ & & $\mathrm{X}$ \\
\hline Constant & $\begin{array}{c}88.18^{* * *} \\
(26.96)\end{array}$ & $\begin{array}{c}88.15^{* * *} \\
(26.88)\end{array}$ & $\begin{array}{c}82.41^{* * *} \\
(27.85)\end{array}$ & $\begin{array}{c}86.57^{* * *} \\
(27.08)\end{array}$ & $\begin{array}{c}224.29 * * * \\
(26.55)\end{array}$ & $\begin{array}{c}81.16^{* * * *} \\
(28.00)\end{array}$ \\
\hline Observations & 8,748 & 8,748 & 8,748 & 8,748 & 8,748 & 8,748 \\
\hline Adjusted R-squared & 0.27 & 0.27 & 0.27 & 0.27 & 0.04 & 0.27 \\
\hline Number of countries & 21 & 21 & 21 & 21 & 21 & 21 \\
\hline
\end{tabular}

Table 15: Regression of the level of currency risk (measured in basis points) on the yearly growth rate of the principal-export monthly price. The dummy variable Core takes on a value of 1 for the core countries identified in Table 2, zero otherwise. $\mathrm{x}$ represents an interaction. All regressions have country fixed effects, $* * * \mathrm{p}<0.01$, ${ }^{* *} \mathrm{p}<0.05,{ }^{*} \mathrm{p}<0.1$. Robust standard errors in parentheses clustered at the country level. 